\title{
Проблема логического противоречия и русская религиозная философия ${ }^{1}$
}

\author{
Б. В. Бирюков, И. П. Прядко
}

\begin{abstract}
This article touches upon the logical ideas of two Russian philosophers of a beginning XX century - the discoverer of imaginary logic N.A.Vasiljew, and P.A. Florensky, author of the solid work. By instruments of the classic proposition logic make explication of the Florensky's doctrine. The imaginary logic of Vasiljew is compared by logical comprehension of Florensky. At the same time Vasiljew's logic is perfectly correctly, but it is based on philosophical principles. It is demonstrated, a distinction of the theological contexts theirs logical doctrines.
\end{abstract}

Ключевые слова: Флоренский, Васильев, логическое противоречие, история логики, неклассические логики

\section{ЧАСТЬ ПЕРВАЯ}

\section{1 Логико-философские идеи Серебряного века: современный взгляд}

Оценка заслуг и ценностного содержания русской философии рубежа XIX-XX вв. на сегодняшний день стала одной из самых острых проблем - слишком сходна ситуация начала нового века с тем, что переживала Россия столетие тому назад. В литературе по этому вопросу мы находим разные суждения. Один из подходов можно назвать православно ориентированным. Он включает критику произведений отечественных философов с весьма консервативных позиций. С этой точки зрения выводы русской философии не соответствуют стилю мышления, укорененному в тысячелетней отечественной традиции; в рамках данного подхода отмечаются «неправославные», западные истоки идей многих русских мыслителей. Так, А.С. Хомяков иногда оценивается

\footnotetext{
${ }^{1}$ Статья написана при поддержке РФФИ; грант № 08-06-00267а «П. А. Флоренский: философско-логические идеи и математическая логика как средство экспликации философско-теологических воззрений».
} 
как «имманентист» протестантского толка, как продолжатель линии немецких романтиков [40, с. 72]. Далеко не все принимается в трудах всеединцев: Вл.С. Соловьева, Е.Н. Трубецкого, С.Л. Франка. Но еще менее связанными с национальной почвой при таком подходе выглядят идеи Н.А. Бердяева, Л.И. Шестова, Д.С. Мережковского, гениального «литературного провокатора» В.В. Розанова.

Это одна крайность. Наряду с ней существует другой подход, в рамках которого критика русской философии ведется с «западнических» позиций. Адептами подобных, как правило, либеральных мировоззренческих философем отечественная традиция видится как маргинальное явление, не представляющее в масштабах истории мировой мысли большого интереса. Безусловно негативно трактуются патриотические мотивы в историософских работах русских мыслителей. В контексте критики, ориентированной на западные либеральные ценности, выводы русских философов отвергаются потому, что они якобы не отвечают современным представлениям о «политкорректности». Ставится знак равенства между историософски-религиозными идеями корифеев русской мысли Серебряного века и программными заявлениями некоторых современных политиков консервативной ориентации.

Ни первая, ни вторая из приведенных трактовок русской философии не представляется нам справедливой. Отечественное философское наследие - явление многогранное, сложное: не все в нем следует принимать, но и не все отвергать. Общемировоззренческие выводы отечественных авторов Серебряного века требуют взвешенных оценок.

Поиск причин тех трагедий и триумфов, которые наблюдались в русской истории, пытаются искать в социальной психологии, в географии страны (евразийцы), в геополитике и даже в биологии. Мы же считаем, что в поиске ответов на интересующие нас вопросы полезным будет обращение к логике $e^{2}$.

В таком случае возникает вопрос, могут ли особенности национальной психики и специфика народного миросозерцания

\footnotetext{
${ }^{2}$ В этом отношении интересно исследование Б.М. Шуранова «Русская логика переломной эпохи (1880-1930) в социо-культрологическом аспекте» [48].
} 
найти отражение в логических закономерностях, в наиболее часто используемых схемах мышления? Можно ли увязать философию как «эпоху, постигнутую в умозрении» (Гегель), с разработками в области логической неклассичности? Может быть, есть способ обнаружить причины многих общественных изменений путем отвлечения от конкретного нелогического содержания, что и предполагает наука логики? Мы убеждены, что правомерна по меньшей мере постановка подобных вопросов.

В настоящей статье рассматриваются логико-философские концепции двух известных русских мыслителей начала XX века - Н.А. Васильева и П.А. Флоренского. Если о творчестве Павла Александровича Флоренского идут достаточно острые, но плодотворные споры, то философские взгляды первого - Николая Александровича Васильева некоторыми авторами объявляются малоинтересными, «неполиткорректными» и не заслуживающими обсуждения. Подобным образом еще до революции относился к ним такой философски настроенный математик, как С.А. Богомолов [50]. В 20-е годы XX века логические идеи Н.А. Васильева критиковались с позиций марксистской диалектики как формалистические [3]. Только в 60-80-е годы стараниями отечественных логиков В.А. Смирнова, В.А. Бажанова, бразильской исследовательницы А. Арруды и других - спустя 30-40 лет после первого этапа их активного обсуждения - взгляды эти были открыты вновь и введены в широкий научный оборот [33], [34], [4], [51], [52]. Примерно то же можно сказать об историко-психологических и философско-исторических воззрениях казанского ученого [18]. Неприятие его общественнонаучных выводов ${ }^{3}$ сегодня свидетельствует лишь о нашем историческом инфантилизме, о неумении ценить отечественное интеллектуальное наследие и о бездумном преклонении перед чужими авторитетами.

Обращаясь к Флоренскому, мы видим, как эволюционировала его философия. Еще в «Воспоминаниях о детстве» взгляд философа на мир обрел твердую веру в наполненность каждого явления смыслом ${ }^{4}$. Поиск этого смысла в последующие годы

\footnotetext{
${ }^{3}$ Критике подобного неприятия посвящена статья И.П. Прядко [29].

43десь мы опираемся на статью [44, с. 185 и далее].
} 
становления Флоренского как мыслителя привел его к созданию знаменитого сочинения «Столп и утверждение истины» ${ }^{5}$; и это развитие завершилось стройным православным мировоззрением, выраженным в последующих работах ученого.

Находясь на пути к своему главному творению, о. Павел ощутил сущностное родство «Эллады и Лавры, античной духовности и московско-русского православия XIV-XV вв.». Фундаментом его духовного мира стало «сближение христианства и платонизма, русского православия и эллинской мистериальной религии» [44, с. 185]. В этом смысле Флоренский в определенном отношении воплощал в своем творчестве единство двух крайностей русской мысли, с констатации которых мы начали настоящую статью. Его мысль органически влилась в отечественный религиозно-философский поиск, предполагавший как освоение западной философии, так и - это прежде всего - разработку «вечных» тем русского интеллектуального сознания: соборности, всеединства, эсхатологии.

Ограничивая наши рассмотрения логико-философской ориентацией, мы ни в коей мере не хотим умалять иные подходы к интересующей нас проблематике. Здесь достаточно назвать ощутимое представительство в предреволюционном интеллектуальном пространстве России неокантианства - о нем мы тоже будем говорить в настоящей статье. Одно из ответвлений последнего - в лице русских представителей марбургской школы нашло у нас своих пропагандистов, ожидающих от его изучения «впечатляющих открытий» [24]. Думается, что значимость кантовской традиции на русской почве не стоит преувеличивать, но свою роль она сыграла как раз в том аспекте, который нас интересует: как мы увидим, данная традиция явилась одним из идейных истоков, питавших отечественную логическую неклассичность.

\footnotetext{
${ }^{5}$ Название этого труда повторяет слова ап. Павла, сказавшего: «. . чтобы $<\ldots>$ ты знал, как должно поступать в доме Божьем, который есть Церковь Бога живаго, столп и утверждение Истины» (I Тим. 3,15) (курсив наш. - Б.Б., И.П.).
} 


\section{2 Постановка проблемы}

Наверное, для начала XX века трудно найти двух до такой степени непохожих философов, как Николай Александрович Васильев и о. Павел Александрович Флоренский. С одной стороны, кончивший безумием реформатор логики - мыслитель, чаявший грядущий рационально-мистический синтез по образцу гностического. С другой стороны, православный священник, сочетавший разработку проблем православного богословия с научными занятиями. С одной стороны, размеренная жизнь Казани, среда университетских светил, кадетов и позитивистов по преимуществу, с другой стороны, Москва с ее полуязыческиполухристианской культурой Серебряного века. Судьба и обстановка, в которой Васильеву и Флоренскому приходилось работать и жить, а главное, направление мысли этих философов были совершенно разными. Это несходство, казалось бы, исключает попытку провести между ними параллель. Однако область, где сопоставление выбранных нами фигур возможно и даже желательно, существует. Эта область - логика, шире - дискурсивное мышление - вместе с его теоретико-познавательными аспектами и телеологическими коннотациями.

Оба мыслителя - Васильев и Флоренский - явились реформаторами данной почтенной науки, со времен Аристотеля и до середины XIX века в целом избегавшей кардинального пересмотра своих положений. Оселком, на котором Васильев и Флоренский оттачивали свои реформаторские идеи, была идея противоречия, шире - антиномичности. Оба давали ей неклассические интерпретации. Здесь - главная точка соприкосновения учений Флоренского и Васильева. Но если, как мы уже говорили, взгляды первого широко известны и вполне определенны в них выражен опыт христианского познания как преодоления субъектом своей «самости», отдельности, изложенный в упомянутом фундаментальном труде мыслителя, где логика находит достойное место [41], то философское творчество второго менее известно. Идеи логической неклассичности не получили у Васильева развернутой теоретической разработки: из-за тяжелой болезни творческая деятельность ученого прекратилась очень рано. Однако его статьи и рецензии свидетельствовали, что, рассматривая познавательную практику, мыслитель из Казани 
пришел к заключению о необходимости при разработке «логики противоречия» учитывать гносеологическое значение религиозной веры и вообще при логических рассмотрениях иметь в виду духовную сферу общественного бытия ${ }^{6}$.

В самом деле, Н.А. Васильев принимал во внимание не только широко известные тогда в России западные источники, например статьи Анри Пуанкаре, но и работы А.С. Хомякова и Вл.С. Соловьева. Именно в контексте их установок оценивал он «Последние мысли» французского математика и мыслителя, говорившего о недостаточности для человека одних только рационально-логических схем познания; Васильев соглашался с корифеем западной науки в том, что жизнь состоит из поступков, а поступок есть акт нашей воли и веры [30].

Нам представляется, что некоторый теологический компонент в воззрениях Васильева позволяет говорить о сходстве его учения с религиозно-философскими идеями Серебряного века. В статье «Логика и металогика» [20, с. 115], рассуждая по поводу закона противоречия, ученый апеллирует к мыслящему Субъекту, сверхчеловеческому по своей природе, а потому «не умеющему» ошибаться. Сознание такого Существа, по Васильеву, не знает закона противоречия, поскольку Ему - этому Существу - нечего опровергать [20, с. 119]. Говоря о сверхчеловеческом мышлении и вводя его в контекст создаваемой им схемы неклассической логики, ученый из Казани связал свой психологизм с теизмом, говоря о металогике - логике без отрицания как о логике Божества. Правда, сделал он это как-то вскользь, не придавая своим словам, возможно, большого значения. И тем не менее это был существенный штрих в философскологическом учении Васильева. K этому вопросу мы вскоре вернемся.

Когда Флоренский ставил задачу уяснения природы антиномичности и, значит, противоречия, он не знал, что за ее решение с другого конца уже взялся его современник - Н.А. Васильев. При сходстве мотивов, побуждавших Васильева и Флоренского исследовать проблему логического противоречия, между их взглядами имелись существенные различия. Прежде всего, один из них - о. Павел - связывал антиномичность с истиной, трак-

\footnotetext{
${ }^{6}$ Мы уже касались этого вопроса. См. [10].
} 
туемой в богословском духе. Ничего этого у Васильева мы не находим. Религиозность, о которой Васильев рассуждал в своих историософских работах, носила слишком общий и неопределенный, - во всяком случае неправославный, - характер. Только некоторые детали позволяют нам говорить о принадлежности учений Васильева и Флоренского единой умозрительной традиции. Но именно эти детали будут для нас существенны.

В центр своих рассмотрений Васильев поставил закон противоречия, а религиозный мыслитель Флоренский исходил из закона тождества, считая законы противоречия и исключенного третьего его «неизбежными спутниками». Богословские импликации, без учета которых немыслимо понять философию о. Павла, существенны потому, что именно в их свете - т.е. в свете омоусианских установок, противопоставляемых внехристиански-рационалистическим омиусианским установкам, - приобретают смысл его гносеологические выкладки ${ }^{7}$.

Однако антиномичность - и это следует подчеркнуть особо Флоренский не замыкает в пределах богословия. Он указывает на древность идеи сочетания противоположностей, называя имена философов античности - Гераклита, элейцев, Платона, мыслителей Нового времени - Николая Кузанского, Гегеля, даже Ницше. Идея антиномичности, пишет он, ныне «высказывается даже в специальных дисциплинах», и как пример приводит лингвистику, математику, физику и механику, этику, эстетику и логику (имея в виду в последнем случае, по-видимому, И. Канта) [41, том II, с. 686-687].

Используемый Флоренским логический аппарат будет в дальнейшем нами подробно описан. Здесь мы ограничимся рядом замечаний. В отличие от Н.А. Васильева, исходившего из аристотелевой силлогистики и не обращавшегося к современной ему математической логике, о. Павел достаточно владел аппаратом «логистики». Таково первое замечание. Смысл другого состоит в следующем. Н.А. Васильев в своих логических построениях предполагал равноправие истины и лжи: они для него две возможные попытки суждения. Вводя противоречивые логические формулы, казанский философ допускал их бинарную

\footnotetext{
7 Этимология этих понятий получит разъяснение в дальнейшем изложении.
} 
истинностно-ложностную оценку. Не то Флоренский. Истина для него не «равноправна» лжи, и в своих логико-психологических выводах он исходит из непреложной истинности как богословских догматов, так и антиномических категорий. В статье Б.В. Бирюкова [7] показано, что логическая формула, выражающая тезис «Священное Писание и догматы христианства непротиворечивы», верна при условии истинности его антецедента, утверждающего, что соответствующее предложение высказано в состоянии духовного просветления. Все это нуждается в детальном исследовании, к которому мы и приступим.

Наконец, последнее замечание. Сравнивая подход к логике Флоренского и Васильева, мы обнаруживаем, что, в отличие от казанского ученого, логические рассуждения о. Павла включали противопоставление, с одной стороны, логики, восходящей к Аристотелю, а с другой стороны, современной ему западной логики неокантианцев (Г. Риккерт), которую он называл гносеологической логикой, а также символической логики. На «логикоалгебраический алгоритм», писал о. Павел, мы смотрим «под углом зрения гносеологической логики» [41, том II, с. 622]. При этом решительно отвергается присущая западной философской традиции «логизации науки» установка на рационализацию всего мышления.

Напротив, Н.А. Васильев не был категорическим противником рационализма, хотя и понимал его ограниченность. Отдавая, как и о. Павел, должное логическим идеям неокантианцев - правда, не столько западных, сколько русских, - он не принимал в расчет достижения математической логики. Здесь проявилось известное отставание Васильева, который в гораздо меньшей мере, чем Флоренский, был знаком с мировой логической литературой.

K сказанному добавим несколько слов о социально-историческом контексте логических размышлений Васильева и Флоренского. Социальная противоречивость издавна привлекала внимание философов, социологов, культурологов. Например, исследователи политического и цивилизационного процесса Нового времени и сегодня обращают внимание на противоречивый ха- 
рактер продолжающей быть актуальной «триединой» политической формулы, получившей хождение во времена Французской революции и «эмансипационных» движений XIX-XX вв.: «свобода, равенство и братство». Каждый элемент этой формулы противоречит двум остальным: семейные узы и семейная иерархия (братство) исключает свободу; свобода не совместима с равенством, поскольку приводит к неравенству социальных статусов индивидов, и т.д.

Думается, социальная противоречивость тоже была одной из тех причин, которые создавали обгективную потребность в теориях, рассматривающих противоречие как одно из свойств высказываний формального языка логики. Социальную конфликтность, т.е. ситуацию, когда налицо противоположные тенденции (силы, партии, социальные группы), в диалектическом мышлении издавна представляли «формулой» $A$ и не- $A$.

Истоком логической неклассичности для той эпохи были не только общественно-научные, но и некоторые естественнонаучные идеи. Приведем один пример. Нильс Бор (1885-1962 гг.) в рассматриваемый период дал превосходный анализ соотношения теоретического и эмпирического в естествознании. На основе этого он сформулировал постулаты, в которых противоречие выступало необходимым инструментом естественнонаучного исследования. Датский физик не только не отбрасывал противоречащие суждения, но делал их отправными точками его теории. Нильс Бор, таким образом, проявил себя не только в области физики, он оказался незаурядным мыслителем, разрабатывавшим парадигмальные концепты естествознания XX века. Он, в частности, указал на принципиальное для теории различие между частным и предельным случаем (ньютонова механика как предельный случай специальной теории относительности).

Здесь возникает вопрос, в какой мере отечественные религиозно-философские умозрения, социальные противоречия и естественнонаучные открытия можно считать факторами, побудившими русскую мысль к поиску логики, которая ныне называется паранепротиворечивой, а также к попыткам построения учения об антиномичности познания. Мы надеемся, что анализ концепций Н.А. Васильева и П.А. Флоренского будет содействовать освещению данной проблемы. 


\section{3 Металогика Н.А. Васильева}

Мы начнем наше рассмотрение с того, что Н.А. Васильев назвал металогикой, так как здесь в явной форме представлены религиозные импликации казанского мыслителя. Васильев назвал металогику сухим минимумом, дополнить который могут формальная (эмпирическая) и воображаемая (паранепротиворечивая) логики, более пригодные для нужд исследования окружающего мира. При этом он отверг онтологический статус закона противоречия. Вместо этого ученый склонен был говорить о самонепротиворечивости: требовании, предъявляемом к эмпирически данному мышлению человека.

Анализируя закон противоречия, Васильев учитывал критику этого закона, которая изложена в книге Фр. Полана «Логика противоречий» [54]. Н.А. Васильева, в то время еще магистра (1913 г.), привлекла мысль западного ученого об относительности данного закона, заложенной в самой его формулировке: «Утверждение и отрицание не могут быть верны „в одном и том же отношении". Но определить в каждом конкретном случае, имеется ли тут одно и то же отношение, бывает очень трудно. Представим себе купца, который утверждал бы, что одна арифметика действительна для исчисления его долгов, а другая действительна для исчисления его имущества. Он мог бы указать, что тут утверждение и отрицание имеют место не в одном и том же отношении, а в разных» [17, с. 364].

Считая выводы французского психолога заслуживающими внимания, Н.А. Васильев предостерегал от смешения реальных противоположностей и логических противоречий. Движение мысли в ходе исследования объекта, отказ от одних суждений науки и принятие в качестве истинных других, антагонизмы социального мира, ненависть и одновременно любовь к одному и тому же лицу - это, по Васильеву, не должно трактоваться как логические противоречия. Все это, согласно его взглядам, свидетельствует о наличии внутренне противоречивых объектов. Когда мы сталкиваемся с объектами последнего рода, мы можем, согласно Васильеву, говорить о противоположностях, но не можем говорить об отрицании одного другим - одной противоположности другой противоположностью.

Между тем, отрицания в логике (в классической, формаль- 
ной) все же есть. Как же смотреть на них с точки зрения «бедной» - а на деле самой возвышенной - логики (т.е. металогики)? По Васильеву, отрицательные суждения - и психологически, и логически - предполагают возможность ошибки, заблуждения: они выражают несовершенство человеческого мышления, выступая его случайными акииденииями. Тут у Васильева, судя по всему, речь идет о погрешности, грехе, зле, - о том, что Отцы церкви понимали как недостаток, отсутствие чего-то необходимого в тварном мире. Таким образом, рассуждение Васильева об утверждающем истину Духе отвечало не только установкам философов русского Серебряного века, но и шло в русле учений православных авторитетов прошлого, которые понимали ложь как отсутствие бытия, как то, что отвергнуто и осуждено от века. Васильев полагал, что металогика прикосновенна миру умных сущностей, - миру, в котором исключена всякая погрешность, всякое несовершенство, неизбежное в мире дольнем.

Васильев не конкретизировал свое учение о металогике. Единственное требование, которое предъявлял мыслитель, - очистить мышление от всего, что ему доставляет опыт. Казанский логик подчеркивал: «Если устранить то, что устранимо и эмпирично, останется неустранимая рациональная логика. Ее мы и предлагаем назвать металогикой. $<\ldots>$ Различие между металогикой и эмпирической логикой есть прежде всего различие между рациональным и эмпирическим (или, точнее, рационально-эмпирическим, так как эмпирическое в чистом виде не может существовать, так как и в эмпирической логике есть рациональные элементы)» [20, с. 115]. Связанная с Божеством металогика, судя по всему, не нуждается и в законе достаточного основания: ведь установить, связаны ли суждения причинно, можно только из их внелогического содержания. В металогике, где основание и следствие могут быть только истинными, истинным будет и соответствующее импликативное сложное суждение. «Металогика, - уточняет свою мысль Васильев, относится к эмпирической логике как абстрактное к конкретному, как бедное к богатому, как минимальное к максимальному. Металогика - это то, что обще всем логикам, и поэтому она беднее их содержанием» [20, с. 116]. Для казанского мыслителя металогика - это только возможность логики, но не сама логика. 
Мысль Васильева о совершенной и одновременно минимальной логике, в которой действует принцип «исключенного второго», может быть рассмотрена как логическая экспликация рассуждений отечественных философов Серебряного века о всеединстве. Наиболее рельефно данная доктрина отражена в работах последователей Вл.С. Соловьева, к числу которых принадлежали Е.Н. Трубецкой, Л.П. Карсавин, С.Л. Франк (о соответствующих идеях П.А. Флоренского мы скажем ниже). Исходя из онтологической общности всех предметов, сущих в мире, и понимая эти предметы как индивидуации Всеединого начала, философы данного направления утверждали, что злое в мире есть только недостаток, неполнота добра, возникающая в силу неокончательного усвоения Божественной сущности. Зла, таким образом, нет: есть различные уровни приобщения к добру. Логически это и предполагает отсутствие необходимости что-либо отрицать в мире, созданном Богом: ведь это значило бы, по мысли всеединцев, отрицать и Творца мира. Данный вывод, быть может, в большей степени отвечающий Божественному замыслу о человеке и мире, а не реальному положению вещей, будет справедлив для мира нематериальных идей, мира Божества. Но именно для мышления Бога предназначалась металогика Васильева.

Заметим, что представление о всеединстве не является для России чем-то новым - оно не придумано ни русским логиком, ни религиозными философами Серебряного века. Оно коренилось в самой основе отечественной умозрительной традиции и определяло специфику восточно-христианского философского и культурно-религиозного дискурса. В своих основных чертах оно было дано в Евангелии.

Ниже мы проследим, каким образом умозрение мыслителей Серебряного века повлияло на развитие логических теорий паранепротиворечивости и антиномичности. Здесь существенны прежде всего философско-религиозные идеи П.А. Флоренского.

\section{4 Истина как проблема онтологии и гносеологии}

Обращение к религии и, шире, к вере в трансцендентальный Абсолют для Флоренского, как отмечают исследователи его творчества, было вызвано возникшей в молодости острой потреб- 
ностью не только обрести критерии достоверности знания (не находя их на почве научной рациональности, философ обратился к интуиции как одному из средств постижения истины), но и вообще - найти жизнестроительные принципы, необходимые для выработки цельного взгляда на мир. Именно поэтому и в науке, и в философии, но особенно в религиозной традиции о. Павел стремился найти ответы на столь мучавшие его вопросы. Осмысление, а иногда и новое прочтение сохраненных традицией религиозных текстов, предпочтение, отдаваемое предлогическому и сверхлогическому перед рациональным, внимание к математике и Платону - все это для Флоренского находилось в русле усилий по обретению истины, было связано с поиском ответа на вопрос: чем она - истина - является. Ввиду особой важности этого, задаваемого религиозным мыслителем, вопроса, отметим сложившиеся в философии представления об истине, истинности. Ведь вопрос: что есть истина и как отличить ее от заблуждений и преднамеренной лжи - имеет не только теоретический, но и насущный практический смысл. В разных течениях философии науки XIX-XX вв. вопрос об истинности знаний рассматривался как один из самых трудных, а такие авторы, как Поппер, даже объявили его не имеющим для научной теории самостоятельного смысла, повторяя вслед за Гёте: «Гораздо легче найти ошибку, чем истину».

Распространенные в настоящее время дефиниции истины, на наш взгляд, недостаточно глубоки. Истину характеризуют как правильное представление о действительности; как мысль, которая соответствует своему предмету, т.е. передает его таким, каков он есть; как соответствие познания изучаемому; как знание, соответствующее предмету, совпадающее с ним. Эти «определения», как очевидно, несут в себе, по сути, одинаковое содержание. Наиболее естественным является понимание истины как того, что с той или иной мерой адекватности отражает реальный порядок вещей.

То специфическое свойство человеческого знания, что оно, как правило, бывает лишь отчасти истинным, в начале XX века с особой силой подчеркивал С.И. Поварнин. В книге о теории и практике спора он продемонстрировал, что в научной полемике ее участники, как правило, обладают истиной лишь в какой-то 
степени, и каждая из сторон может впадать в то или иное заблуждение. Поварнин здесь подчеркивает следующее: «росты и несомненны (для обычных целей) лишь истины нашего обычного опыта; например, я не сомневаюсь, что спал в эту ночь и утром пил чай. Но чем сложнее и отвлеченнее истина, тем менее она „проста“" и тем труднее достигнуть правильной уверенности в ней. Между тем огромное множество людей совершенно не понимает этого» $[27$, с. 20]. Русский логик сетовал, что в эвристической практике неуловимость «полной» - абсолютной истины не учитывается вовсе, а преобладают безапелляционные выводы и суждения. «Не следует забывать, - предупреждал С.И.Поварнин, - что большинство „истин“, выходящих за пределы простого обычного опыта, тоже не „чистые истины“, что в них тоже есть примесь заблуждения большего или меньшего, которого мы оценить теперь не в силах» [Tам же].

Понимание истины как отношения знания к познаваемому принималось и Флоренским, в частности, когда русский богослов обращался к проблеме соответствия образа, явленного в православной иконе, горнему Первообразу. Так, о. Павел совершенно справедливо охарактеризовал эстетически совершенные реалистические произведения религиозной живописи эпохи Возрождения как лжесвидетельства, в своем духовном содержании сильно уступающие образцам византийского религиозного искусства. Здесь он констатировал: «Религиозная живопись Запада, начиная с Возрождения, была сплошной художественной неправдой» [42, с. 66]. В работе «Иконостас» он говорил о Троице Андрея Рублева как о наиболее убедительном свидетельстве истинности христианства: «Из всех философских доказательств Бытия Божия наиболее убедительно именно то, о котором даже не упоминается в учебниках; примерно оно может быть построено умозаключением: „Есть Троица Рублева, следовательно, есть Бог"» [42, с. 67]. Сходное о. Павел писал и о православных святых: их бытие как бы показывает, что есть Истина: ЩПдвижник не словами своими, а самим собою, вместе со словами своими, а не отвлеченно, не отвлеченной аргументацией, свидетельствует и доказывает истину - истину реальности, подлинной реальности» $[42$, с. 57]. 
Не меньшей проблемой, чем проблема соответствия образа реальности самой реальности является проблема языка, на котором фиксируются как результаты научного исследования, так и выводы богословско-философского характера. Вопрос здесь стоит так: как определить степень того, в какой мере знание, выраженное в символической форме, отвечает тому, что изучается, - физическим процессам, историческим событиям, процессам сознания, религиозным переживаниям? Можно ли изменчивые и текучие явления реальности, столь многообразной в своих формах и проявлениях, вместить в жесткие рамки понятийнокатегориального аппарата?

Недоверие к знаку, символу не раз проявлялось и в религиозных учениях, и в богословской практике. Так, в Средние века особое значение придавалось языку, на котором писался и читался религиозный текст. Грамматике и синтаксису при этом уделяли первоочередное внимание. Именно поэтому Флоренский, толкуя смысл сложных философско-богословских терминов, обращается к греческому языку первоисточников восточно-христианской традиции, стремясь таким способом восстановить истинное значение понятий.

Для Флоренского как мыслителя религиозного проблема Истины лежала, разумеется, не столько в плоскости гносеологии, сколько онтологии. Можно сказать, что истина была для него не чmo, а Kmo. Что же касается проблем гносеологии, то о. Павел прочно увязывал их с практикой Богопознания.

Реальность Истины, взятой как Абсолют, по Флоренскому, и в полном соответствии с ортодоксальной точкой зрения - помогает человеку укорениться в Боге. Она, образно говоря, позволяет личности-индивиду прикоснуться к Личности-Христу. Это акт духовного восхождения, требующий от рассудка подвига самоотречения. Русский философ-богослов подчеркивал, что познающему субъекту необходимо учитывать ограниченность рационально-логических схем, неточных и слишком бедных, а потому не позволяющих приблизиться к Истине (с большой буквы); для этого надо возвыситься до позиции разума-Логоса. Это означает приятие такого мышления, которое требует оперирования антиномиями. Чтобы формализовать такое мышление, необходима логическая теория антиномичности. 
Знакомясь с огромной литературой, посвященной П.А.Флоренскому, мы с удивлением обнаруживаем, что вне поля исследовательского внимания до сих пор остаются его логические взгляды, его учение о логике антиномичности и его попытки применить математическую логику к решению отдельных богословских вопросов. Последний пример: на прошедшей в апреле 2007 г. в Московском университете и Московской Духовной академии юбилейной научной конференции, посвященной «125-летию со дня рождения и 70-летию мученической кончины философа, богослова, ученого, священника Павла Александровича Флоренского», его логическим воззрениям не было посвящено ни одного доклада! Настоящая статья служит в какой-то мере восполнению этого пробела.

\section{5 Бесконечность - потенциальная или актуальная?}

Как известно, П.А. Флоренский получил блестящее математическое образование, окончив соответствующее отделение физикоматематического факультета Московского университета. Однако он не пошел по математической стезе (о чем сожалел Николай Николаевич Лузин, учившийся тоже на математическом отделении, но только годом младше), а поступил в Московскую духовную академию, по окончании которой получил там доцентуру. Защищенная им в 1914 году в МДА магистерская диссертация «О духовной истине. Опыт православной теодицеи» явилась основой рассматриваемого нами в настоящей работе главного труда Флоренского.

Математическая образованность о. Павла позволила ему одним из первых в России понять огромную значимость учения о множествах Георга Кантора и для математики, и для философии, и для богословия. К этому добавилось то, что о. Павел владел основоположениями и аппаратом математической логики, что дало ему возможность рассматривать проблемы разума, истины и противоречия не только в теологических, но и в чисто научных, причем точных, терминах.

Канторово учение о множествах явилось одной из первых областей математики, изучая которые, Флоренский столкнул- 
ся с феноменом антиномичности. Свидетельством этого явилась опубликованная им в 1904 году - году окончания им Московского университета и поступления в Духовную академию - статья «О символах бесконечности» [37]. В ней он констатирует, что пренебрежение дистинкцией понятий актуальной и потенциальной бесконечности привело в истории человеческой мысли ко многим недоразумениям.

Вслед за Кантором Флоренский признает подлинной бесконечностью актуальную, считая потенциальную бесконечность «вспомогательным» понятием; известное с античных времен как «неопределенное» (апейрон Анаксимандра), оно в философии Нового времени получило название дурной бесконечности. Это, писал Флоренский, есть переменное конечное количество, тогда как актуальная бесконечность есть постоянное, константа, обогащенная признаком - быть больше «всякой конечной константы, как бы великой мы ее ни взяли». В этом смысле, писал Флоренский, мы можем сказать, что «могущество Божие актуальнобесконечно, потому что оно, будучи определенным (в Боге нет изменения), в то же время больше всякого конечного могущества» $[37$, с. $177-178]$.

Понятие о бесконечности, возникшее в эллинской науке в связи с попытками уяснения природы Универсума, было перенесено на почву логики Аристотелем ${ }^{8}$. Здесь-то и выяснилось (Флоренский ссылается на диалог Шеллинга «Бруно»), что «каждое понятие есть бесконечность, потому что оно объединяет собою множество представлений, которое не является конечным; но так как объем понятия, по существу дела, вполне определен и дан, то эта бесконечность не может быть ничем иным, кроме актуальной бесконечности»; далее, и всякое «суждение, всякая теорема носят в себе актуальную бесконечность» ${ }^{9}$, и в этом вся сила логического мышления, как указывал еще Сократ [37, c. 178].

Обосновывая необходимость введения актуальной бесконечности, Флоренский говорит о том, что потенциальная бесконечность предполагает беспредельное изменение, но для этого необ-

\footnotetext{
8 Здесь Флоренский ссылается на известного историка науки, французского ученого Поля Таннери.

${ }^{9}$ Следует ссылка на труд Анри Пуанкаре «Наука и гипотеза».
} 
ходима область изменения, которая сама уже не может меняться, так как в противном случае потребовалась бы «область изменения для области [изменения] и т.д.». Поэтому «всякая потенциальная бесконечность уже предполагает существование актуальной бесконечности как своего сверх-конечного предела» [37, c. 179].

Обращаясь к учению Кантора, Флоренский называет три различные области, где реализуется актуально бесконечное: в Боге (in Deo sive natura naturante), в мире, где актуально-бесконечное «может быть предположено in concreto, в зависимом мире, в твари, in natura naturata (Кантор называет еe «Transfinitum») и в духе - in abstracto, поскольку дух „имеет возможность познавать Transfinitum в природе и, до известной степени, Absolutum в Боге“» [37, с. 181-182]. Флоренский приводит два аргумента против актуальной бесконечности, выдвинутых ранне-христианским философом и богословом Оригеном, - что в тварях нельзя мыслить бесконечного и что, если бы бесконечное множество существовало, оно бы постигалось числом, но числа бесконечного не существует. Кантор же своим учением о множествах опроверг эти аргументы. Он показал, что символы бесконечности можно создать и что «не только абсолютный дух, но и мы можем иметь идею о бесконечном множестве» [37, с. 185].

В годы, когда писалась рассматриваемая нами статья, терминология теории множеств еще не сложилась. Канторовскую «науку о множестве и единстве в их взаимоотношениях» П.А. Флоренский называл «наукой о группах». В терминах «групп» он и излагал основные положения канторовского учения. Он привел основные разъяснения Кантора, касающиеся понятия множества («группы») и различия между конечными и бесконечными множествами, а также отношения между множеством и составляющими его элементами; это отношение предполагает принцип исключенного третьего: «в сущности элемента уже определено, что он либо подпадет под определение [данной] группы, либо нет» [37, с. 199].

В статье систематически излагались основные положения учения Кантора о бесконечных множествах - вводились понятия о мощности множеств и их эквивалентности, понятия упорядоченного и вполне упорядоченного множества, а также операции над 
множествами; и, наконец, перед читателем вставала во всем объеме развитая Кантором иерархия кардинальных (количественных) и ординальных (порядковых) чисел. Ныне все это широко известно, но иначе обстояли дела в начале прошлого века. Поэтому к выкладкам Флоренского следует подходить, учитывая его эпоху.

Можно констатировать, что в альтернативе: бесконечность потенциальная или актуальная - Флоренский выбрал вторую, считая, что первая должна быть отброшена, так как ведет к логическому противоречию. Прошло немного времени, и с критикой актуально бесконечного и связанного с ним безоговорочного признания принципа исключенного третьего выступил Э.Я.Л. Брауэр. Со своей стороны, упомянутый Н.Н. Лузин был склонен критически относиться к идее актуальной бесконечности и поэтому был осторожен в применении принципа исключенного третьего, когда речь заходила о бесконечных совокупностях объектов.

$$
* * *
$$

Заключительная часть статьи Флоренского звучит как гимн гению Кантора, который совершил, по его словам, подвиг великой веры - веры в возможность создания символов бесконечности. О. Павел в связи с этим писал: Если мы ничто перед Абсолютным, то все же мы - нравственно однородны с Ним, мы можем постигать Его, но не прямо, а в символах; мы носим в себе трансфинитное, сверх-конечное; мы, - космос, - не являемся чем-то конечным, прямо противоположным Божеству, мы трансфинитны, „середина между всем и ничем“» [37, с. 232].

По мысли Флоренского, Г. Кантор показал, как создать символы для Бесконечного, как можно реализовать «внутренне непротиворечивую идею Трансфинита». Со своей стороны, о. Павел видел, что сама идея актуальной бесконечности не лишена противоречия. В пробной лекции pro venia legendi, прочитанной им в 1908 году на Совете МДА [38] и посвященной космологическим антиномиям Иммануила Канта, он хотя и выдвигает - в качестве главного возражения немецкому мыслителю «неприятие им во внимание идеи актуальной бесконечности», 
вместе с тем указывает на антиномичность последней. «Признаки данности - законченности и бесконечности - беспредельности - сочетаются в идее актуальной бесконечности, которая дана, но не исчерпьвается никаким конечным рядом синтезов». В опыте никогда не дана бесконечность, но всегда только конечное, но не просто конечное: опыт всегда потенциально бесконечен; он - бесконечность в возможности; никогда не данной, но всегда имеющейся в виду. «Абсолютность, законченность, бесконечность - это отражение в опыте собственного стремления $p a-$ зума, его неудовлетворенности конечным и условным» [38, с. 5]. О. Павел заключает: «Идея о возможнноти антиномий разума - самая глубокая и самая плодотворная из идей Канта. Но доказательство действительного их существования - кажется, самое непрочное место „Критики [чистого разума]“” [38, с. 27, 28](см. также Прибавление «Экскурс об антиномической структуре разума», с. 30 ).

Восполняя этот недостаток, Флоренский помещает в данной статье «Прибавление» - «Экскурс об антиномической структуре разума». В нем дан абрис того, что в развернутой форме изложено в его труде «Столп и утверждение истины». Поэтому теперь мы перейдем к трактовке антиномии самим П.А. Флоренским.

\section{6 Идея антиномичности истины у Флоренского}

Идея противоречивости бытия и познания - очень древняя. Уже на этапе возникновения логики как самостоятельной отрасли философского знания обращалось внимание на антиномичность (апорийность) как одну из существенных философскологических проблем. Так, античные философы - софисты, стоики, элеаты, скептики пытались как-то справиться с парадоксами типа «Лжец», «Куча», «Спрятанный». Они, далее, открыли апории, ведущие к противоречиям, связанным с мысленным отображением движения, пространства и времени. Была осознана антиномичность отношения множественности и единственности, обнаружена трудность индивидуации предметов мысли. Средневековые схоласты в своих логических компендиумах вводили особый раздел - O неразрешимых предложениях. Наконец, широкую известность приобрели кантовские антиномии чисто- 
го разума, о которых говорил Флоренский, а также гегелевское учение о противоречии как основе «диалектики». Однако все эти рассмотрения не приводили ни к последовательному анализу идеи антиномичности, основанному на учете данных логики, ни к созданию сколько-нибудь разработанных логических теорий противоречивости. Свое веское слово здесь сказали, с одной стороны, П.А. Флоренский, отстаивавший тезис об антиномичности истины, а с другой - Н.А. Васильев, создавший исторически первый вариант «логики противоречий».

Противоречивость - антиномичность, апорийность - у о. Павла выступает в качестве важнейшего элемента интерпретации православного вероучения. Проблеме противоречия посвящено «Прибавление»в его статье об антиномиях Канта, а главное «шестое письмо» его фундаментального труда. Противоречие для Флоренского связано с Истиной (с большой буквы) и истинами, явленными в человеческих суждениях и понятиях. «Там, на небе - единая Истина; у нас - множество истин, осколков Истины, не конгруэнтных друг с другом» [41, том I, с. 158]. «Существование многих истин есть лишь иное выражение самого факта существования твари» [41, том I, с. 143]. Но «в твари данная $<\ldots>$ истина должна быть монограммою Божества» [41, том I, c. 145]. Истина, полагал Флоренский, есть «такое суждение, которое содержит в себе и предел всех отменений его, или, иначе, истина есть суждение самопротиворечивое. $<\ldots>$ Истина потому и есть истина, что не боится никаких оспариваний; а не боится их потому, что сама говорит против себя более, чем может сказать какое-угодно отрицание; но это само-отрицание свое истина сочетает с утверждением. Для рассудка истина есть противоречие, и это противоречие делается явным, лишь только истина получает словесную формулировку. $<\ldots>$ Тезис и антитезис вместе образуют выражение истины. Другими словами, истина есть антиномия, и не может не быть таковою» [41, том I, c. 147].

Истина как «предел всех отменений суждения» означает, по Флоренскому, то, что истинное суждение предусматривает все возражения на него и отвечает на них. Антиномией она является потому, что на вопрос: «Почему $A$ есть $A$ ?» следует ответ: «"Потому $A$ есть $A$, что вечно бывая не- $A$, в этом не- $A$ оно нахо- 
дит свое утверждение как $A$ “. Точнее: $A$ потому есть $A$, что оно есть не- $A$. Не будучи равно $A$, т.е. самому себе, - оно в вечном порядке бытия всегда устанавливается силою не- $A$, как $A »[41$, том I, с. 47].

Итак, основной тезис рассуждений религиозного мыслителя состоит в том, что любое $A$ может быть познано в сопоставлении с не- $A$, т.е. через свое другое; не- $A$ является условием существования $A$, условием его различения. Без не- $A$ мы бы $A$ не заметили, и отсутствовала бы возможность выделения $A$ из предметов универсума.

Мы еще вернемся к предложенному Флоренским толкованию истины как антиномии. Здесь же отметим, что о. Павел, с одной стороны, указывал на древность идеи антиномичности, а с другой стороны, на ее распространенность в науке. Понятие «антиномия», писал Флоренский, появляется не ранее Канта, да и то только в «Критике чистого разума» - до этого слово «антиномия» было юридическим и, отчасти, богословским термином. Но «идея необходимой само-противоречивости рассудка» - древняя, и Флоренский говорит об эллинской идее сочетания противоположностей, называя, как мы уже говорили, Гераклита и Платона, элейцев и Николая Кузанского, Гегеля и Ницше, и др. Что касается науки, то о. Павел указал на присутствие идеи антиномичности даже в специальных дисциплинах в лингвистике (здесь упомянуто имя Вильгельма Гумбольдта), в математике (Г. Кантор, Б. Больцано, А. Пуанкаре), в богословии (Флоренский пишет, что антиномии христианства особенно подчеркивает Д.С.Мережковский), в физике и механике, в социологии (Н. Кареев), в этике (уже названное сочинение Канта, гл.V), в эстетике (Кант, «Критика способности суждения», $\S 55-57)$, и, конечно, в логике.

Вряд ли следует сомневаться в том, что идея антиномичности, как она рассматривалась о. Павлом, отражала специфику мышления той переходной эпохи, и если ее и нельзя считать фактором, побудившим ученых приступить к поиску формализованных логических систем, допускающих противоречие, то сигналом того, что время такого рода логик настало, - можно. И подтверждением здесь служит не только концепция «воображаемой логики» Н.А. Васильева, но и идеи некоторых русских неоканти- 
анцев. Однако прежде чем о них говорить, рассмотрим детальнее осененные светом православия логико-методологические воззрения о. Павла.

\section{7 Критика рассудочного знания. Проблема достоверности}

Исходный пункт мысли П.Флоренского - это неуловимость для логических принципов церковности как жизни в духе. Согласно о. Павлу, «... для всякого, желающего понять православие, есть только один способ - прямой опыт православия $\langle\ldots>$ можно стать католиком или протестантом по книгам $\langle\ldots>$ Но, чтобы стать православным, надо окунуться разумом в самую стихию православия, зажить православно, - и нет иного пути» [41, том I, с. 8]. Читая эти слова, можно вспомнить о покойном Ю.А. Шрейдере, принявшим именно католицизм и в его «ментальном стиле» сочинившим свой труд по этике $[46]^{10}$.

Для Флоренского вера «", доказательствами от разума“, вера по толстовской формуле $<\ldots>$ есть заскорузлый, злой, жестокий и каменный нарост в сердце, который не допускает его к Богу», крамола против Бога. «„Разумная вера“, - согласно отцу Павлу, - есть смрад пред Богом». Отсюда оправдание тертуллиановского «Credo quia absurdum»: что «умер Сын Божий, это достоверно, потому что нелепо; что Он, погребенный, воскрес, несомненно, потому что это невозможно». Это верно «вопреки стопам рассудка» [41, том I, с. 61,64], [41, том II, с. 638].

Комментируя этот взгляд во втором томе своего труда, где разъясняются некоторые «частности», о которых говорилось в томе первом, Флоренский писал: «Что жизнь недоступна рассудку, - об этом у нас рассуждали многие, особенно же настаивали на этом пункте у нас славянофилы, преимущественно А.С.Хомяков и И.В.Киреевский $<\ldots>$ но сверх-рассудочность духовной жизни, „зоэ“, о которой говорят славянофилы, не

\footnotetext{
${ }^{10} \mathrm{~B}$ предисловии к данной книге, между прочим, подчеркивается, что в ней «богословский контекст изложения носит скорее общехристианский, чем специфически католический характер» (с. 3). Математическая интерпретация проблем морали особенно отчетливо просматривается в Главе 8 этого исследования (см. параграфы «Алгебра комбинирования добра и зла», «Формальная структура рефлексии»). См. аналогичные установки в [47].
} 
должна быть смешиваема с иррациональностью естественной жизни, как биологического явления, bios». На недоступность такой жизни - bios - формулам рассудка в свое время указывал Гёте, а в настоящее время «особенно сильно и подробно» говорит Анри Бергсон ${ }^{11}$.

Не отвергая научной значимости рассудочного знания, о. Павел на первое место ставил познание интуитивное. Говоря, что истины даны человеку в его суждениях, Флоренский писал: «Суждение, данное непосредственно, есть само-очевидность интуиции - evidentia, $\epsilon \nu \epsilon \rho \gamma \epsilon \iota \alpha$. Далее она дробится: Она может быть само-очевидностью чувственного опыта, и тогда критерий истины есть критерий эмпириков внешнего опыта (эмпириокритицистов и проч.): „Достоверно все то, что может быть сведено к непосредственным восприятиям органов чувств; достоверно восприятие объекта". - Она может быть само-очевидностью интеллектуального опыта, и критерием истины в этом случае будет критерий эмпириков внутреннего опыта (трансценденталистов и проч.), а именно: „Достоверно все то, что приводится к аксиоматическим положениям рассудка; достоверно самовосприятие субгекта". - И, наконец, само-очевидность интуиции может быть само-очевидностью интуиции мистической; получается критерий истины, как он разумеется большинством мистиков (особенно индусских): „Достоверно все то, что остается, когда отвеяно все неприводимое к восприятию субъект-объекта, достоверно лишь восприятие субгект-обгекта, в котором нет расщепления на субъект и объект"» [41, том I, с. 24-25].

Но интуитивный критерий свмоочевидности, какого бы рода он ни был, для Флоренского недостаточен, так как не доставляет достоверности. Поэтому необходимо обращение к опосре-

\footnotetext{
${ }^{11}$ П.А. Флоренский здесь указывает на труды Анри Бергсона, к тому времени имевшиеся в русском переводе: «Материя и память. Исследование об отношении тела к духу». Перев. с фр. А.Баулера. СПб., 1911; «Время и свобода воли». Перев. С.И. Гессена. М.: Изд. журнала «Русская мысль», 1910; «Творческая эволюция». Перев. М. Булгакова. М., 1909. В числе работ о Бергсоне названы: Ю. Кронер. «Творческая эволюция (А.Бергсон)» // «Логос», русск. изд., кн.1, М., 1910, и Б.Н.Бобынин. «Философия Бергсона» // «Вопросы философии и психологии», т. XXII (1911), кн.108 (III) май-июнь, и кн. 109 (IV); последнего автора не следует путать с историком математики и логики Виктором Викторовичем Бобыниным. См. [41, том II, c. 608-609].
} 
дованным суждениям - к тому, что «принято называть дискурсией, ибо здесь разум discurrit, перебегает» от одного суждения к другому [41, том I, с. 30]. Такую достоверность Флоренский называет отвлеченно-логической, в отличие от интуитивной, «конкретно-выразительной» [41, том I, с. 32]. Требование достоверности означает решение: ничего не принимать без доказательства; последнее предполагает установление аподиктической связи между логическим подлежащим суждения и его логическим сказуемым.

\section{8 Два вида закона тождества}

«Второе письмо: сомнение» о. Павел начинает с утверждения, что для теоретической мысли «Столп Истины» - это достоверность. На пути к ней неизбежно возникает вопрос о справедливости закона тождества - того, что «,вообще всякая данность есть она сама: всякое $A$ есть $A$ "» - но для разума « $A=A$ бессмысленное равенство» [41, том I, с. 25]. Это, по Флоренскому, вытекает из явлений множественности и изменения, присущих и внешнему миру, и миру внутреннему, и, наконец, миру мистических восприятий. Между тем рассудок, в отличие от разума, считает, что лишь $A$, равное самому себе и не равное тому, что не есть $A$, является подлинно сущим. Рассудок и разум противны друг другу: «Жизнь - текучая, несамотождественная $<\ldots>$ может быть прозрачна для разума $<\ldots>$ А рассудок враждебен жизни» [41, том I, с. 29-30].

Эти слова о. Павла не следует понимать как отвержение рассудочного знания. Флоренский внимательно вглядывался в него, различая, например, ясность и отчетливость мысли, с одной стороны, и ее объяснение - с другой. Мыслить ясно и отчетливо означает: «стоять на $A$ и не сбиваться с него на не- $A$. „Объяснять“, т.е. „определять“ и „доказывать“ - это значит идти от $A$ к $B,-$ к тому, что есть не- $A$. Но чтобы идти от $A$ к $Б$, надо сперва установить $A$ как $A$, т.е. чтобы „объяснять“ и „доказывать“ $A$, надо сперва „мыслить его ясно и отчетливо“». Для этого $A$ надо понимать, т.е. объяснять его, определять, доказывать [41, том I, с. 485$]^{12}$.

\footnotetext{
${ }^{12}$ Сходную формулировку мы находим в статье об антиномиях Канта: «Мыслить ясно и отчетливо - это значит под $A$ разуметь именно $A$ и ничего
} 
Доказательственный процесс, однако, сталкивается с той трудностью, что впадает в «дурную бесконечность». Ибо переход от суждения обосновывающего к суждению обосновываемому для рассудка не имеет конца: «... раз уж кто $<\ldots>$ вступил на путь обгяснений и обоснований», то на «вопрос „Где же конец?“ отвечаем: „Конца нет“. Есть $<\ldots>$ regressus in indefinitum - нисхождение в серый туман „дурной“ бесконечности»; иными словами, допущение подобного «перехода от $n$ к $(n+1)$, каково бы ни было $n \gg$, влечет мысль в бесконечность in potentia [41, том I, c. 32]. И в этом состоит ахиллесова пята рационализма. Чтобы избежать в этом процессе движение ad indefinitum, закон тождества, согласно о. Павлу, надо дополнить законом достаточного основания, позволяющим «остановку мысли». Эти законы составляют, по Флоренскому, «наличную норму рассудка» $[41$, том I, с. 485-486].

Таким образом, Флоренский не отбрасывает закон тождества, а дает ему свое истолкование, и когда нужно, например, опровергнуть взгляды скептиков, он ссылается именно на этот закон. Основное требование скепсиса - считать всякое недоказанное положение недостоверным - приводит к состоянию воздержания от всякого высказывания, или «эпохэ» $-\epsilon \pi \omega \chi \eta$. $E \pi \omega \chi \eta$ означает «остановку, задержку, это остановка мышления», так как означает принятие тезиса: «Я ничего не утверждаю; не утверждаю и того, что ничего не утверждаю», или ниже: «Я утверждаю, что ничего не утверждаю $\left(A^{\prime}\right)$; я не утверждаю, что ничего не утверждаю $(A ") »$. Здесь, указывает Флоренский, нарушается закон тождества $A=A$. Ибо «об одном и том же подлежащем, - об утверждении своем, $A,-$ в одном и том же отношении высказываются противоречивые сказуемые:

- $A$ есть $A$;

- $A$ не есть $A \gg[41$, том I, с. $35-36]$, [41, том II, с. 628].

более; объяснять и доказывать - это значит выходить мыслию за пределы $A$ к Б. Мыслить ясно и отчетливо - это значит стоять на $A$ и не сбиваться с него на не- $A$. Объяснять (определять и доказывать) - это значит идти от $A$ к $E,-$ к тому, что есть не- $A$. Но, чтобы идти от $A$ к $Б$, надо сперва установить $A$ как $A$, т.е. чтобы объяснять и доказывать $A$, надо сперва мыслить его ясно и отчетливо» $[38$, с. 3$]$. 
«Так получится пирроническое, поистине огненное („пюр“ огонь) терзание» [41, том I, с. 37]. Итак, завершает ход своей мысли о. Павел, позиция скептицизма, как и путь рационализма, не ведет ни к чему.

Таким образом, закон тождества для Флоренского - это совокупность аналитических законов мышления: закон тождества берется вместе с его неизбежными спутниками - законом противоречия и законом исключенного третьего, ибо они, все три, говорят с разных сторон об одном и том же. $\mathrm{K}$ аналитическим законам, по Флоренскому, как мы уже говорили, надо добавить закон достаточного основания. Но закону этому о. Павел не придавал большого значения. Это и понятно, так как обоснование суждения $A$ он видел прежде всего в его сопоставлении с не- $A$.

В самом деле, мы читаем у о. Павла, что в плане устремления к обоснованию понятий и суждений - т.е. «в плане определения и доказательства - каждое $A$ должно иметь свою основу в не- $A ;\langle\ldots\rangle$ Когда мы спрашиваем: „Что есть $A$ ?", то нам дают ответ: „ $A$ есть $D^{“}$, т.е., другими словами, выводят $A$ из его само-тождества „ $A=A$ “ и приравнивают его $Б$, тому, что не есть тождественно $A \gg[41$, том I, с. 484-485].

Что «достаточное основание»в изложении о. Павла с трудом находит место в рассудочной логике, видно из того, как трактуется вопрос о том, что значит «мыслить ясно и отчетливо». Выше мы кратко изложили его мысли по этому поводу. Теперь настало время привести полностью соответствующие слова о. Павла: "„Мыслить ясно и отчетливо“ - это значит под $A$ разуметь именно $A$ и ничего более; „обгяснять“ и „доказывать“это значит выходить мыслию за пределы $A$, к Б. „Мъслить ясно и отчетливо" - это значит стоять на $A$ и не сбиваться с него на не-А. „Обгяснять“ т.е. „определять" и „доказывать“ - это значит идти от $A$ к $D-$ к тому, что есть не- $A$. Но, чтобы идти от $A$ к $D$, надо сперва установить $A$, как $A$, т.е. чтобы „объяснять“ или „доказывать“ $A$, надо сперва „мыслить его ясно и отчетливо“, надо понимать это $A$, т.е. надо „объяснять" его, - т.е. 
„определять" и „доказыватъ“ - надо устанавливать $A$, как не$A$. Но для последнего опять-таки надо установить $A$, как $A$. И так идет процесс ad indefinitum. Одна функция разума предполагает другую; но, вместе, одна - исключает другую. Всякое не-тождественное объяснение приводит $A$ к не- $A$. Всякое ясное и отчетливое мышление устанавливает тождество $A=A$. Утверждение $A$ как $A$ и утверждение его как не- $A$ - таковы два основных момента мысли» [41, том I, с. 484-485].

Закон тождества как «первая норма рассудка» требует «остановки мысли», а как вторая - «беспредельного движения» мысли; первая «понуждает установить $A$, а вторая свести его к $Б$ »; эта вторая норма есть закон достаточного основания [41, том I, c. 486].

Но как остановить это бесконечное сведение $A$ к $D, E$ к $B$ и т.д. - эту трудность о. Павел решает, ссылаясь на антиномичность мышления, о чем пойдет речь позже.

\section{9 Формальная и математическая логика}

Следует подчеркнуть, что Флоренский достаточно хорошо ориентировался в современной ему логике - формальной («философской») и математической, а также в теории множеств. Ему были известны труды не только Георга Кантора, но и Бертрана Рассела, Анри Пуанкаре. Вообще, логическая эрудиция о.Павла чрезвычайно широка. В примечании № 211 к «Письму шестому: противоречие» мы находим перечень трудов по математической логике («логистике»), принадлежащих зарубежным и русским ученым. Список начинается с выпусков I и II «Опытов математического изложения логики» Виктора Викторовича Бобынина, где представлены работы Буля, Шрёдера и Роберта Грассмана. Указаны работы П. Порецкого. Зарубежная «логистика» представлена С. Джевонсом, Уайтхедом (указан его известный труд «Универсальная алгебра»), Б. Расселом, Дж. Пеано, БуралиФорти, Хью Макколом. Назвав труд Б. Рассела «Принципы математики» и знаменитые «Principia mathematica» Уайтхеда и Рассела (Том I), Флоренский замечает: «Труды Шрёдера, Уайтхеда и Ресселя [так в то время транскрибировалось имя этого ученого] - капитальнейшие $<\ldots>$ изложения логистики: на основе теории классов, теории отношений и теории пропозицио- 
нальных функций» [41, том II, с. 688]. Все это позволило о. Павлу овладеть логической техникой, где главным руководством для него служила известная книга Л. Кутюра [25].

Но в логических познаниях о. Павла имелся один существенный пробел: ему были неизвестны ни основополагающие для современной формы математической логики труды Готлоба Фреге (1848-1925 гг.), ни работы Давида Гильберта, заложившие основы аксиоматического метода. Знакомство с работами Фреге, думается, не отразилось бы - существенно, во всяком случае, на логических взглядах Флоренского. Иначе обстоит дело с аксиоматическим методом Гильберта. В нем о. Павел нашел бы существенные возражения против своих рассуждений о «регрессе в бесконечность» доказательственного процесса, правда, не на «разумном», а на рассудочном, т.е. рациональном уровне.

На логику Флоренский смотрел, конечно, через призму своего антирационализма. Не владея аксиоматическим методом, он считал, что рассудочный доказательственный процесс означает regressus ad indefinitum. В этой части его критика рационализма была не вполне оправдана. Но когда мы читаем у него о том, что рационализм - «будь то рационализм Фихте, Шеллинга, Гегеля, современных марбуржцев или, наконец, логистиков», в сущности занят одной задачею: «изгнать из области мысли все то, что не воспостроено чисто-логически, т.е. рационализировать все мышление», - мы должны с ним согласиться. И критический пафос о. Павла в отношении подобной установки совершенно понятен, тем более что, говоря о «логизации науки», он указывает на арифметизацию, проводимую в основаниях математики. Он метко заметил, что в этом случае интуиция, изгоняемая в дверь, неизбежно влетает в окно [41, том II, с. 625-626].

Это верно уже в применении к известной концепции финитизма Давида Гильберта. В книге Б.В. Бирюкова и В.Н. Тростникова эта мысль выражена в словах: «Гильберт считал, что необходимым условием надежности логических рассуждений является наглядное представление определенных внелогических конкретных объектов; эти объекты должны быть обозримы, четко отличны друг от друга, а их структура должна усматриваться вместе с ними как нечто, не сводимое к чему-либо другому» [11, с. 112]. Речь здесь идет о знаках, используемых в матема- 
тике и логике, об их постижении по сути дела на интуитивном уровне, не поддающемся математико-логической экспликации. Флоренский был прав, говоря, что в этом дан «опыт наглядного приведения к абсурду самого принципа рационалистического» [41, том II, с. 626]. С этой точки зрения он имел бы все основания возражать против «терапевтической» функции аксиоматического метода, когда мы находимся на уровне разума.

Стоит обратить внимание на то, как Флоренский «разводит» формальную и символическую логику. Формальная логика, основанная Аристотелем, монистична в том смысле, что берет в качестве первичного либо понятия (и, опираясь на них, осуществляет последующие логические конструкции), либо суждения (служащие той же цели). «Символическая же логика, основываясь на соотносительности и неразделимости суждений и понятий, существенно дуалистична $<\ldots>$ не бывает ни суждений без понятий, ни понятий - без суждений $<\ldots>$ Понятия и суждения суть такие элементы мышления, которые, будучи всегда вместе, различаются не безотносительно, а лишь соотносительно, и, вне своего соотношения, они не могут быть рассматриваемы как различные $<\ldots>$ [В символической логике] при алгорифмических выкладках нам нет ни малейшей надобности знать, имеем ли мы дело с суждениями или с понятиями; полученная формула будет равно справедлива и при той и при другой интерпретации, так что каждая формула представляет собою две теоремы - одну из исчисления классов, а другую из исчисления предложений» $[41 \text {, том II, с. } 621]^{13}$.

Заметим, что в своем учении об антиномичности познания и истины Флоренский - ради простоты, как он говорит, - имел в виду логику суждений; «и тогда истина оказалась антиномией суждений $<\ldots>$ в логике понятий мы пришли бы к выводу подобному, а именно, что истина есть антиномия понятий $<\ldots>$ Ведь каждое понятие превращаемо в соответствующее ему суждение, и каждое суждение - в понятие» [41, том I, с. 148].

\footnotetext{
${ }^{13}$ Следует заметить, что Флоренский здесь ссылается на уже упомянутую книгу Л. Кутюра «Алгебра логики».
} 


\section{0 Дискурсивная интуиция и интуитивная дискурсия. Омиусианство и омоусианство}

Преодоление ограниченности «норм рассудка» Флоренский начинает с того, что к аналитическим законам (закону тождества и двум другим его «родственникам») он добавляет закон достаточного основания. Он пишет, что первая из норм рассудка требует «остановки мысли, а вторая - беспредельного движения мысли $\langle\ldots\rangle$. Первая есть закон тождества, а вторая закон достаточного основания» [41, том I, с. 486]. Но это не дает окончательного решения, так как не ясно, как снять это движение. Поэтому о. Павел делает следующий шаг - вводит представление об интуиции-дискурсии. Эта двойственная по положению, но единая по замыслу идея формулируется так: «Истина есть интуиция, которая доказуема, т.е. дискурсивна. $<\ldots>$ Чтобы быть интуитивною, дискурсия должна быть не уходящей в беспредельность, не возможною только, а действительною, актуальною. Дискурсивная интуиция должна содержать в себе синтезированный бесконечный ряд своих обоснований; интуитивная же дискурсия должна синтезировать весь свой беспредельный ряд обоснований в конечность, в единство $<\ldots>$ Дискурсивная интуиция есть интуиция дифференцированная до бесконечности; интуитивная же дискурсия есть дискурсия интегрированная до единства». Итак, Истина есть «конечная бесконечность и бесконечная конечность, или, - выражусь математически, актуальная бесконечностъ» [41, том I, с. 43].

Подчеркивание интуитивной компоненты знания - дара «глубинного зрения», как охарактеризовал интуицию о. Павла С.С. Хоружий [44, с. 185], есть особенность мировоззрения Флоренского. Но это не мешало ему понимать, что научное знание требует постулата единообразия природы. Отстаивая данный тезис, православный философ ссылался на Стенли Джевонса и Джона Стюарта Милля. Но в их учениях, по мнению Флоренского, данный постулат построен на песке. Милль, убежден о. Павел, «по природе софист, опутывающий читателя и самого себя блестящей смесью фактов, цитат и остроумных оборотов» $[41 \text {, том II, с. } 683]^{14}$.

\footnotetext{
14Это - цитата из «Университетского опыта» В.Я. Цингера (М., 1874).
} 
Положение о «единообразии законов природы» является постулатом, без которого невозможна никакая наука. Но постулат этот становится психологической реальностью только при вере в Божественное Слово. «Провидение Божие $<\ldots>$ вот религиозная предпосылка нашей науки», - пишет он [41, том I, с. 126]. Рационально-рассудочному истолкованию знания как «философии плотской», омиусианской, о. Павел противопоставлял омоусианскую философию ${ }^{15}$.

Обратим внимание на то, что речь здесь идет о функциях $p a-$ зума, а не рассудка, а этим категориям Флоренский придавал большое значение, хотя проводимое им их различение не отличалось ясностью. Закон достаточного основания - рассудочныи закон, и он находит свое место, когда заходит речь об объяснении, определении, доказательстве. Но последние понимаются также как функции разума.

Такой взгляд согласуется с тем, в чем Флоренский видел подлинное обоснование закона тождества - не в его низшем, рассудочном виде, но в некотором высшем, разумном, - том, который о. Павел счел высшей формой закона тождества ${ }^{16}$. Так понимаемый закон тождества может быть «животворящим в своей динамике». Ибо: «Вместо пустого, мертвого и формально самотождественного „A=A“, в силу которого $A$ должно было бы быть самостно, само-утверждено $<\ldots>$ мы получили содержательное $\langle\ldots\rangle$, реальное само-тождество $A$, как вечно отвергающего себя и в своем самоотвержении вечно получающего себя. Если в первом случае $A$ есть $A(A=A)$ вследствие исключенности из него всего ( - и его самого в его конкретности! 一), то

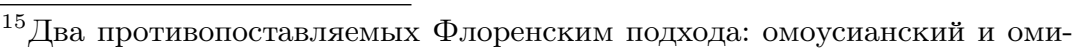
усианский - лежат в основе познавательных практик двух культур. Омоусианство или «единосущие» характерно для исследователя, стоящего на почве православия. Здесь в акте познания исследователь восстанавливает свое изначальное единство с изучаемым объектом. Омиусианство, которое переводится как «подобосущие», есть установка, ставшая основой для западной науки Нового времени. Омиусианство - это путь анализа, путь разложения цельного объекта на составные части. Противоположность данного подхода православному омоусианскому очевидна.

${ }^{16}$ Ее открытие о. Павел связывал с именем архимандрита Серапиона Машкина, автора трудов «Опыт системы христианской философии» и «Система философии: Опыт научного синтеза», 1903, существовавших в виде рукописей.
} 
теперь $A$ есть $A$ через утверждение себя как не- $A$, через усвоение и уподобление себе всего» [41, том I, с. 47-48].

В конце первого тома своего главного труда о. Павел пишет, что антиномичность основного строения рассудка ставит вопрос: «Как возможен рассудок?» Отвечая на него, Флоренский утверждает, что рассудок имеет две основы - начало конечности и начало бесконечности. При этом «ткань рассудка», сотканная из конечности и бесконечности - дурной бесконечности, беспредельности, - раздирается в противоречиях. Рассудок равно нуждается в обеих этих нормах. Но он не может пользоваться обеими ими, ибо они не совместимы. Рассудок насквозь «антиномичен». «„Рассудок возможен тогда, когда мыслимая им конечность есть бесконечность, и, наоборот, когда мыслимая в рассудке бесконечность есть конечность“; или наконец: „Рассудок возможен, если дана ему Абсолютная Актуальная Бесконечность“» [41, том I, с. 488] - а «Столп Истины» - это Церковь, это Дух Святой. Человек может достичь только того, что «сквозь зияющие трещины человеческого рассудка видна бывает „лазурь вечности“». Это непостижимо, но это - так. И мы знаем, что «„Бог Авраама, Исаака, Иакова, а не Бог философов и ученых“ приходит к нам. ..» $[41 \text {, том I, с. 489 }]^{17}$.

\section{1 Попытка построения логической теории антиномичности}

Поскольку, как уже отмечалось, для Флоренского «Истина есть антиномия», он счел необходимым создание формально-логической теории антиномичности [41, том I, с. 148]. Пытаясь показать, в чем она состоит, о. Павел прибег к тому, что он назвал «логическим алгоритмом». И тут обнаружилось, что, владея логической техникой, он не до конца продумал вопрос о том, как следует согласовывать логические выкладки со своей богословской установкой.

Речь идет о рассуждениях о. Павла, как они представлены в его «Шестом письме: противоречие». Логические рассуждения

\footnotetext{
17 Здесь о. Павел цитирует Блеза Паскаля, его знаменитый текст, известный под названием «амулета Паскаля». В томе II своего труда Флоренский посвятил ему «разъяснение» XXV, в котором привел французский текст, дал его русский перевод и его богословский комментарий. Паскаля о. Павел называл «проникновенным мыслителем». См. [41, том II, с. 577-581].
} 
ведутся ученым в базисе: импликация (つ), дизъюнкция, называемая им логическим сложением $(\cup)$, конъюнкция, называемая логическим умножением $(\cap)$, и отрицание, выражаемое короткой чертой, помещаемой перед формулой; вместо скобок используются точки, как это было принято в некоторых математикологических построениях того времени. В дальнейшем мы вместо точек будем пользоваться скобками. Флоренский считал, что рассуждения об антиномиях естественно возникают из приема доказательства путем сведения к нелепости. Прием этот передается им формулой

(IV) $(-p \supset p) \supset p$

(используется нумерация формул самого Флоренского). Подразумеваемое этой формулой рассуждение Флоренский считает парадоксальным, хотя и оправдываемым в «логистике»; из этой формулы, заменяя в ней букву $p$ ее отрицанием $-p$ и применяя закон снятия двойного отрицания, он получает формулу

(IX) $(p \supset-p) \supset-p$.

Формулы (IV) и (IX), считает он, и «слагают собою антиномию $P \gg[41$, том I, с. 151].

У читателя-логика может возникнуть вопрос, правомерно ли говорить (как это делает о. Павел) о «парадоксальности» формул (IV) и (IX). Конечно, с точки зрения классической пропозициональной логики это кажется странным, так как упомянутые формулы тождественно-истинны. Но в них «просвечивает» то, что известно как парадоксы материальной импликации.

Антиномия, по мысли о. Павла, символически определяется как формула

(X) $P=(p \cap-p) \cap \mathrm{V}$,

где V есть знак истины. Далее читаем: «ереводя формулу $(\mathrm{X})$ на обычный язык, скажем: „Антиномия есть такое предложение, которое, будучи истинным, содержит в себе совместно тезис и антитезис, так что недоступно никакому возражению“. Прибавка же символа $\mathrm{V}$ поднимает антиномию над плоскостью рассудка и отличает антиномию $P$ от лжи $\Lambda$ (перевернутые $\mathrm{V}$, или $-\mathrm{V})$, лежащей в рассудочной плоскости и определяемой формулой: 
(XI) $\Lambda=p \cap-p »$.

И далее: «По своему составу $P$ нисколько не разнится от простого противоречия $\Lambda$, и, следовательно, в сфере рассудочной лишь авторитет является тем перстом, который отличает истинность $P$ в сравнении с $\Lambda \gg[41$, том I, с. 152$]$.

Как мы увидим, здесь самое существенное - ссылка на авторитет.

Рассматриваемое само по себе, это рассуждение ошибочно. Конгюнктивное присоединение истины $\mathrm{V}$ к противоречивой формуле $p \cap-p$ не обращает выражение $(p \cap-p) \cap \mathrm{V}$ в истину. $P$ оказывается ложным. Делу не помогает ни представление $P$ в видоизмененно-детализированном виде:

$(*)(((-p \supset p) \cap(p \supset-p)) \supset((p \cap-p) \cap-\Lambda)=P$,

правда, сопровождающий ее комментарий содержит ошибку, ибо слова Флоренского - «„если антитезис влечет за собою тезис, и, вместе с тем, тезис влечет антитезис, то совокупность тезиса и антитезиса - если она не ложна, - есть антиномия“"18. Такова формула антиномии» [41, том I, с. 153] - не отвечают сути дела.

Рассмотрим формулу $(*)$. Совокупность тезиса и антитезиса в ней:

$$
(-p \supset p) \cap(p \supset-p)
$$

как раз ложна, так как выразив импликацию через конъюнкцию и отрицание, мы получим формулу противоречия $p \cap-p$; консеквент формулы $\left(^{*}\right)$ тоже ложен, но это уже не имеет значения: формула $P$ истинна в силу ложности антецедента. Сравнивая $P$ в формуле $(*)$ с $P$ в формуле $(\mathrm{X})$, мы видим, что в первой $P$ истинно, а в последней ложно. Естественно считать, что именно формула $(*)$ выражает задуманную Флоренским «логику антиномичности». Такой она представляется рассудочному дискурсу.

Однако как быть с формулой $(\mathrm{X})$ ? Ее следует отнести к сфере разума, где авторитет возвышает ее к сфере рационального. Ниже мы покажем, как можно передать эту мысль о. Павла, оставаясь в пределах логики.

\footnotetext{
${ }^{18}$ Но в логике «совокупность тезиса и антитезиса» не может не быть ложной (курсив наш. - Б.Б., И.П.).
} 
Итак, Истина, согласно Флоренскому, есть антиномия в описанном выше смысле. Но предлагаемое логическое представление антиномичности в сфере рассудка не приводит к истине. Положение, как будто, можно спасти, заменив в формулах (X) и (XII) конъюнктивное введение тождественной истинности $\mathrm{V}$ $(=-\Lambda)$ дизбюнктивным. Но тогда смысл антиномичности сведется к выбору между формально-логическим противоречием и истиной. По-видимому, это не совсем то, что хотел сказать о. Павел.

В самом деле, приводимый в «восьмом письме» пример тезиса и антитезиса, когда Флоренский пишет: «Тезис - „невозможна невозможность всеобщего спасения" - и антитезис „возможна невозможность всеобщего спасения" - явно антиномичны» [41, том I, с. 209], он вряд ли предполагает, что к этим словам для выявления антиномии надо конъюнктивно или дизъюнктивно присоединять истину V.

Очевидно, что, оставаясь в рамках рассудочной логики (а у о. Павла это была классическая логика высказываний), мы к непротиворечивому представлению антиномий не придем. Требуется, учитывая логику рассудка, совершить вместе с тем выход за ее пределы. Как это возможно?

Прежде всего заметим, что «рассудочная» логика отнюдь не бесполезна в богословском анализе. Дело в том, что, приняв православное вероучение - опираясь на его авторитет, - можно производить логическую экспликацию богословских утверждений. Это по сути дела показал сам Флоренский, анализируя «задачу Кэрролла». Выявление смысла его выкладок на эту тему проведено одним из авторов этих строк [7]. Не вдаваясь в детали, опишем возникающую здесь ситуацию.

В помещенном в томе II «разъяснении» XVI, цель которого - достижение «большей осознанности того шага, который мы делаем, когда верим в Истину», Флоренский утверждает, что для этого «полезно рассмотреть соответствующие акту веры умственные процессы in abstracto»; а это, согласно его взгляду, означает решить задачу Льюиса Кэрролла «в ее общем виде» [41, том II, с. 500]. 
Мы сформулируем эту задачу в тех логических терминах, которые были использованы нами выше. В этом случае она принимает следующий вид. Даны посылки

(1) $q \supset r$;

(2) $s \supset(q \supset-r)$.

Выводима ли из них формула $s \supset-q$ ? Флоренский показывает, что данная выводимость в классической пропозициональной логике имеет место, и это используется им для опровержения того, будто Священное Писание и православная догматика противоречивы.

П. Флоренский рассуждает так. Пусть $q$ означает противоречивость Св. Писания и догматики Церкви; $r$ - небожественное их происхождение; $s-$ состояние духовного просветления. Тогда, если имеется $s$ - духовное просветление, мы, используя посылку (2), с помощью правила modus ponens получаем формулу $q \supset-r$, выражающую то, что противоречивость Св. Писания вместе с православными догматами влечет их «не-небожественность», т.е. их божественное происхождение; это - вместе с посылкой (1) $q \supset r$ - приводит к противоречию, заставляющему отвергнуть $q$, т.е. противоречивость православного вероучения.

Главное в этом рассуждении состоит в том, что данное заключение усматривается только в состоянии духовного просветления. Но ведь этот ход мысли применим и к учению об антиномичности Флоренского. Ибо противоречивость разума усматривается лишь духовно просветленным лицом, человеческой личностью, принимающей авторитет Священного писания и Истину Церкви. Это значит, что антиномия $P$ является таковой лишь при условии $s: s \rightarrow \mathrm{P}$, или в развернутой записи:

(3) $s \rightarrow(p \cap-p) \cap \mathrm{V}$, a также

(4) $s \rightarrow((-p \supset p) \&(p \supset-p)) \supset((p \cap-p) \cap-\Lambda$,

где знак $\rightarrow$ означает условную связь, учитывающую смысловое отношение между условием и заключением; связь эта отлична от «рассудочной» материальной импликации (и средством 
ее уточнения являются различные теории «строгой импликации»). Очевидно, что полученные формулы не тождественноложны, и их можно считать логической экспликацией антиномики о.Павла. Правда, с точки зрения математической логики нельзя признать положения формулы (3) истинными. Но опираясь на авторитет Церкви, находясь в состоянии духовного просветления (т.е принимая $s$ ), мы должны признать заключенную в (3) и (4) антиномичность как истину разума.

\section{2 Отношение к логическому наследию античности}

Как видно из предыдущего параграфа, создать логическое учение об антиномиях как истинных утверждениях Флоренскому не удалось. Со своей стороны Н.А. Васильев, не отвергая ложности суждений вида «S есть $P$ и $S$ не есть $P(=S$ есть не- $P)$ », такую теорию разработал; заметим, что этому предшествовала его исследовательская деятельность в области истории и социальной психологии. Естественно, что, сопоставляя логические подходы двух мыслителей, стоит остановиться на некоторых их историко-логических воззрениях.

Если мы обратим внимание на то, как оценивали Васильев и Флоренский предыдущие этапы становления логики, то обнаружим больше различий, чем сходств. Флоренский, судя по его трактату «Столп и утверждение истины», придерживался распространенного в философской историографии мнения, будто логическое учение Аристотеля состоит из трех частей: учений о понятиях, о суждениях и об умозаключениях. Согласно этому представлению, учение о понятиях раскрывается в более раннем произведении Стагирита - «Категориях», а учение о суждениях и об умозаключениях - в поздних его работах: в трактате «Об истолковании» и в «Аналитиках» ${ }^{19}$.

На самом деле ничего подобного у создателя логики не было. Данную схему эллинскому мыслителю приписали комментаторы Нового времени. Они подогнали корпус сочинений Аристотеля под классификацию, сформировавшуюся в позднейший период развития науки, и тем самым навязали древнему автору традиционный ныне школьный шаблон. Флоренский смотрел на

\footnotetext{
${ }^{19}$ Подробную критику такой оценки наследия Аристотеля см. [32, с. 298].
} 
эту классификационную схему как на объект критики, не принимая во внимание того обстоятельства, что понимание Стагиритом задач и структуры логики в эту схему не вписывалось.

Анализ идей Аристотеля, проделанный Васильевым, в этом отношении глубже, чем экскурсы о. Павла в учение «отца логики». Исследователь из Казани, приведя фрагмент из «Второй Аналитики», показал, что его можно толковать в смысле, отличном от того, который приписывался ему традиционными комментаторами. Правда, Васильев начинает лишь с Гегеля и Шопенгауэра, ограничивая тем самым круг «бунтарей» против формальной логики. Но, несмотря на это, анализ, произведенный Васильевым, позволяет и Аристотеля причислить к не вполне твердым сторонникам классической формальной логики (т.е. логики, которую потом назвали аристотелевской!). Ведь античный философ высказывал мысль о неуниверсальности закона исключенного третьего и говорил о наличии «средних» (по-современному «индифферентных») суждений. Существование противоречивых понятийных конструктов допускали стоики - наследники Аристотеля в области логических построений. Однако фрагменты эллинской диалектики, в которых данность третьего ставилась под сомнение, не нашли применения в логических учениях последующих времен; именно поэтому классической стала считаться двузначная логика, именуемая ныне аристотелевской.

\section{3 О неокантианских идеях в русской логике}

В ряде фрагментов своего учения Васильев отталкивался от гносеологических выводов Иммануила Канта - мыслителя, гораздо более близкого ему по времени, чем Аристотель. Далее мы кратко рассмотрим кантианские и неокантианские истоки логической неклассичности в отечественной науке ${ }^{20}$.

Мы видели, что обосновать истинность антиномий средствами классической логики Флоренскому не удалось. Да это и не могло произойти, так как данная логика рассудочно-рационалистична. Но он сумел показать, что логические средства можно использовать при анализе конкретных богословских вопросов.

Вслед за Флоренским можно констатировать, что антиномия

\footnotetext{
${ }^{20}$ Нам уже приходилось писать об этом: [8], [49]. См. также [53].
} 
(буквально - «беззаконие», «противо-мыслие») есть абсолютное противоречие в подлинном смысле. Уже мыслитель-богослов показал, что для «работы» с антиномиями существуют по меньшей мере три их разные трактовки. Один подход состоит в выявлении предпосылки конкретной антиномичности и установлении факта, что отказ от одной (или более, чем одной) из них снимает противоречие. Другой способ связан с «ослаблением» противоречия, содержащегося в антиномии, при этом противоречие оказывается вполне безвредным для данной логической системы (в результате становится невозможно из ослабленного противоречия выводить «все, что угодно»). Наконец, возможно строить логику так, что в числе ее предложений окажутся противоречивые высказывания, и для них (как и для непротиворечивых высказываний) вводится понятие логического следования. Два последних подхода обычно объединяются под названием паранепротиворечивой логики. Нами уже отмечалось, что исторически первой системой такой логики явилась «воображаемая логика» Н.А. Васильева.

Указывали мы и на то, что логическая мысль у Флоренского находилась в пределах двузначной логики (об аспекте его взглядов, который можно считать неявным выходом за ее рамки, мы скажем ниже). Логическую бинарность принимал и Васильев. Как и у Флоренского, проблема противоречия была одним из главных объектов его рассмотрений. Это и понятно. Обращаясь к широкому кругу текстов, написанных корифеями русского религиозного Ренессанса, мы видим, что и в них присутствуют схемы более сложные, чем бинарные, истинностно-ложностные конструкции - характерный признак классической логики. Одной из причин этого было обращение к внутренне противоречивым объектам, которые можно обнаружить среди социальных феноменов. Именно о внутренней противоречивости общественных явлений шла речь у С.А. Аскольдова, Н.А. Бердяева, у авторов «веховского» направления - например, в их статьях, посвященных особенностям русского национального характера. Русский этнос в работах этих мыслителей трактовался как носитель противоположных свойств. Он, если можно так выразиться, есть $A$ и не- $A$ зараз. Глубина противоречий общественного развития определила, согласно представлениям веховцев, 
трагизм русской истории. Этот трагизм и получил «логическое представление» в концепции Н.А. Васильева.

Значительную часть опубликованных работ Васильева составляют рецензии на книги и статьи современных ему западных и отечественных мыслителей, занимавшихся проблемами логики, гносеологии и истории познания. Оценки, которые содержатся в этих работах, позволяют реконструировать положительную часть философского мировоззрения казанского ученого. Мы полагаем, что интерес к неокантианской логике (а Васильев много внимания уделял идеям Риккерта и Виндельбанда, следил за публикациями представителей именно этого направления современной ему теории познания) не мог не оказать влияния на творчество ученого.

Идеи неокантианцев нашли отражение в основных формулировках первой логической работы Васильева о законе исключенного четвертого. Даже положение, в соответствии с которым суждение о единичном предмете является результатом обобщения частных моментов существования данного предмета и наряду с изложением факта несет в себе общее содержание, соответствует тому фрагменту учений Виндельбанда и Риккерта, где речь идет об образовании понятий в гуманитарных науках и об основополагающей роли в этих науках исторических (т.е. единичных) фактов.

Принимая далеко не все в гносеологической логике неокантианцев, Васильев подчеркивал, что теоретическую силу этого философского направления составляют «частности» и «изящные детали» [21, с. 134]. Именно они кажутся интересными русскому логику. Одной из важных неокантианских «деталей» является мысль о том, что в мире «вещей в себе» допустимы противоречивые объекты. Соответствующую идею можно обнаружить, например, у И.И. Лапшина, на которую в связи с этим ссылался Васильев ${ }^{21}$.

\footnotetext{
${ }^{21}$ Иван Иванович Лапшин был крупным специалистом по истории философии и логики. Его капитальный труд - «Законы мышления и формы познания» (СПб., 1906), оказал влияние на последующие отечественные разработки в области неклассической логики. С 1922 г. политэмигрант. В Праге развивал критический метод Канта, связав априоризм немецкого классика с логическими разработками в области создания неклассических формализованных систем. Стремился построить систему «абсолютного им-
} 
Однако Васильев не разделял того негативного отношения к математической логике, которое было характерно для представителей баденской школы неокантианства. В недоверии к математике Васильев видел «Геркулесово распутье» [21, с. 135] современной ему философской логики, ее противоречивость и «старомодность». Ниже мы укажем на некоторые иные точки пересечения васильевской доктрины с неокантианской. А пока отметим, что, создавая воображаемую логику, Васильев, вероятно, принимал во внимание современную ему теорию чисел, основные положения которой были изложены в работах его отца - Александра Васильевича Васильева, профессора математики Казанского университета [14].

Позитивное отношение к неокантианству является, как нам кажется, одним из пунктов сходства идей Н.А. Васильева и П.А. Флоренского. Ведь последний в некоторых вопросах тоже солидаризировался с неокантианцами, подобно им считая суждение «основным актом познания». При сопоставлении классической логики с новыми подходами в этой науке, предложенными последователями Канта, Флоренский отдавал предпочтение гносеологическим схемам баденских философов. Он писал: «Формальная логика, основанная Аристотелем, начинает, как известно, с понятий, и из них построены, далее, суждения. Напротив, гносеологическая логика, особенно в трудах Г. Риккерта, начинает с суждений и при помощи них устанавливает понятия. $<\ldots>$ В первом случае понятия - первичные элементы, а суждения - вторичные, во втором - наоборот, но и та и другая логика сходятся между собой в монистическом понимании логических элементов». И далее, уточняя свои подходы в логике: «На логико-алгебраический алгоритм мы посмотрели под углом зрения именно гносеологической логики, т.е. сочли $<\ldots>$ основным актом познания - суждение» [41, том II, с. 621-622].

При определении того, какая форма мысли является первичной, Васильев, как это видно из его статей, шел дальше Флоренского и неокантианцев. Русский логик выводил отрицательные суждения из умозаключений, т.е. умозаключение считал первоначальной формой мысли. Отрицание Васильев в одних случаях сближал с предложением о несовместимости двух признаков,

манентизма», обосновав невозможность метафизики. 
в других рассматривал его как заключение силлогизма модуca Celarent. Большая посылка этого силлогизма является положением о несовместимости, а меньшая посылка отождествляет предмет с субъектом большей посылки:

$N$ исключает $P$, несовместимо с $P$ (положение несовместимости)

$\underline{S \text { есть } N \text { (малая посылка) }}$

$S$ не есть $P$ (выводное отрицательное суждение).

«Мы обычно не замечаем, - писал Н.А. Васильев, - что при отрицательных суждениях мы имеем дело с выводом. Причина этого заключается в том, что вывод этот является чем-то в высокой степени для нас привычным, и поэтому совершается настолько быстро и механично, что не доходит до сознания» $[22$, c. 61]. Иными словами, умозаключение есть форма мысли, возникающая на этапе, предшествующем осознанной умственной деятельности. Опережая суждение, оно, умозаключение, определяет его характер; операция отрицания в этом случае начинается с подведения менее общего понятия под понятие более общее.

Рассматривая отрицательное суждение как результат силлогистического умозаключения, Васильев настаивал на вторичности, несамостоятельности этих суждений. Аргументация в пользу данного положения, развитая Васильевым в статье «Логика и металогика», опирается на его «полупсихологистские» установки. Утверждая онтологический характер только некоторых логических формул, Васильев подчеркивал психологическую, субъективную обусловленность отрицаний. Отрицание для русского логика - лишь негативная оценка субъектом суждения об объекте, а потому оно увязывалось Васильевым только с человеческим мышлением. Здесь можно усмотреть сходство васильевских рассуждений с выводами Флоренского: ведь понятие как основа логики отвергалось о. Павлом, видимо, в силу его отвлеченного, неконкретного характера. Религиозная философия говорит в таких случаях о немощи человеческого мышления, неспособного избежать ошибок - следствий неверного анализа и обобщения фактов. Результатом ошибок являются неверные понятия (фантастические логосы). Без отрицания этих логосов - 
побочных продуктов человеческого мышления - постигающий мир субъект обойтись не может.

Н.А. Васильев в своих работах не указывал явно на связь между идеей социальной конфликтности, присутствующей в мире, и предлагаемой им «воображаемой логикой». Однако косвенно эта связь прослеживается именно в упомянутой второй большой статье ученого, посвященной идеям паранепротиворечивости [22, с. 61]. В ней, если говорить языком философии, речь идет о вопросе, допустимы ли противоречия в кантовском мире «вещей в себе».

Отметим, что данная проблема интересовала современников Васильева - русских неокантианцев, в том числе и тех, которые разрабатывали логику отношений. Эти исследователи пытались выяснить, мыслима ли контрадикторность в ноуменальном мире, т.е. в мире объектов «самих по себе». Один из представителей данного направления - уже упоминавшийся нами И.И. Лапшин давал на вопрос о допустимости противоречий положительный ответ. Согласно концепции неокантианцев, ноуменальный мир стоит за всеми явлениями природы и общества, т.е. в том числе и за явлениями социальными, охватываемыми, как полагал Васильев, на самой высокой ступени абстракции - философией истории, и более низком (и тем не менее абстрактном) уровне - так называемой «сравнительной историкой»; последняя занимается фиксацией сходных явлений, происходящих на совпадающих этапах развития различных культур. Между тем абстрактные объекты, которые вводит в рассмотрение наука, не относятся к ноуменальному, трансцендентному миру - они принадлежат миру явлений. Не стоят ли за социальными противоречиями ноумены $A$ и не- $A$ ? Мы не можем дать ответа на этот вопрос, но обязаны допустить правомерность его постановки.

\section{4 Непрерывность и дискретность. Разные пути, ведущие к идее логической многозначности}

Начало века в отечественном математическом мышлении ознаменовалось коллизией между установками на непрерывность и на дискретность в истолковании мышления. Собственно говоря, проблема эта была во весь рост поставлена Георгом Кантором, 
но в России она приобрела особый смысл благодаря философскоматематическому творчеству Н.В. Бугаева и П.А. Некрасова. Бугаеву, отцу Андрея Белого, члену-корреспонденту Императорской Академии наук, одному из основателей Московского математического общества, принадлежит идея аритмологии философско-математического направления, в котором результаты теории разрывных функций были распространены на психолого-гносеологические вопросы. Аритмология противопоставлялась аналитике как теории, связанной с идеями биологической эволюции и социального прогресса. «Аритмология, - поясняет современный автор, - говорит о принципиальной неисключаемости свободы, выбора, цели, воли, подвига, творчества $<\ldots>$ Аналитической рассудочной деятельности противостоит озарение» [28].

П.А. Флоренский был знаком с аритмологией, упоминал о математических исследованиях, относящихся к непрерывности и прерывности, связывал их с «логистикой». Ему были известны работы Бугаева, в частности его статья «Математика и научнофилософское миросозерцание» [13], труды П.А. Некрасова. Он указывал на «кванты» Планка, корпускулярную теорию света, на «вечно истинные» парадоксы Зенона; он писал об открытиях в учении об органической эволюции, и при этом называл теории, говорящие о явлениях прерывности в развитии живого мира, о том, что «психологические исследования подсознательной и сверх-сознательной душевной жизни обнаруживают прерывные изменения сознания, прерывность творчества, вдохновения и т.д.» [41, том II, с. 684$]$.

У Флоренского мы читаем: «Вдохновение, творчество, свобода, подвиг, красота, ценность плоти, религия и многое другое только неясно чувствуется, изредка описывается, устанавливается в своей наличности, но стоит вне методов и средств научного исследования, ибо основная их предпосылка, конечно, есть предпосылка связности, предпосылка непрерывности, постепенности. Идея закономерности в существующей форме, решительно неприменима ко всему таковому. Тут - прерывность, а прерывность выходит за пределы нашей науки, не вяжется с основными идеями современного миросозерцания и разрушает его» [41, том I, с. 127]. 
Конечно, прерывное и непрерывное тесно взаимосвязаны: «Мы не можем мыслить процесса, не разлагая его на последовательность стационарных состояний - на последовательности моментов неизменности. И мы не можем также мыслить непрерывное, continuum, не разлагая его на прерывную совокупность точечных элементов». И в рассудке это проявляется в соотношении его статики и динамики, которые исключают друг друга, хотя вместе с тем «не могут быть друг без друга» [41, том I, c. 484].

В статье о «пифагоровых числах» $[39]^{22}$ Флоренский сопоставил пифагорейскую идею о «выразимости всего целым числом» с канторовским учением о бесконечных множествах с его понятиями количественных и порядковых чисел; он писал о необходимости «изучать числа, - конкретные, изображенные числа, как индивидуальности, как первоорганизмы, схемы и первообразы всего устроенного и организованного» [39, с. 634].

Классическая логика, конечно, дискретна, но нам теперь известны такие ее «неклассические» направления, как многозначные и бесконечнозначные логические системы. В связи с этим стоит задержаться на неклассических логических идеях, которые, с одной стороны, можно вычитать у Флоренского, и которые, с другой стороны, содержались в «воображаемой» логике Васильева.

У о. Павла мы встречаем две идеи, которые можно отнести к логической неклассичности. Первая - это «триипостасное» истолкование истины, вторая - мысль о разных «степенях» знания.

Сначала рассмотрим первую идею. В логико-теологическом построении о. Павла мы встречаем - впрочем, в весьма неявной форме, - мысль о трехзначности логического; она была представлена в названном выше «трехипостасном» истолковании истины. Данное истолкование всегда связывалось, как хорошо известно, с христианской идеей Троицы. В логическом же плане

\footnotetext{
${ }^{22}$ Опубликована по манускрипту, хранящемуся в архиве о, Павла. По времени создания относится к концу 20-х годов.
} 
мысль о троичности возникала из сопоставления $A$ и не- $A$, пронизывавшем все мышление Флоренского.

Во «Втором письме: сомнении» главного труда о. Павла ставится вопрос о том, что собой представляет само-доказательный Субъект. Ответ, который на него дается, гласит: «Он таков, что он есть $A$ и не- $A$. Обозначим для ясности не- $A$ через Б. Что же - $Б$ ? Б есть $Б$, но оно само было бы слепым $Б$, если бы не было вместе и не-Б. Что же такое не-Б? Если оно просто $A$, то $A$ и $Б$ были бы тождественны. $A$, будучи $A$ и $Б$, было бы одним простым, голым $A$, равно как и Б. Чтобы не было простого тождесловия „ $A=A “$ “, чтобы было реальное равенство „A есть $A$, ибо $A$ есть не- $A$ “, необходимо, чтобы $D<\ldots>$ было зараз „Б и не- ${ }^{\prime} ;$ последнее, т.е. не-Б для ясности обозначим через $B$. Через $B$ круг может замкнуться, ибо в его „другом“, в не- $B,-A$ находит себя как $A .\langle\ldots\rangle A$ от другого $\langle\ldots\rangle$, т.е. от $B$, опосредованно получает себя, но уже „доказанным“, уже установленным. То же относится и к каждому из субъектов $A, Б, B$ троичного отношения». Субъект истины, продолжает о. Павел, есть отношение Трех. Истина есть «Бесконечный акт Трех в Единстве $<\ldots>$ Истина есть единая сущность о трех ипостасях» $[41$, том I, с. 48-49].

$\mathrm{B}$ «разъяснении» XXIII - «К методологии исторической критики» Флоренский подходит к вопросу с другой стороны. Он вводит представление о вариативности «количества знания». Он убежден: «Всякое суждение и всякое умозаключение в области исторических наук есть суждение с коэффициентом вероятности, и если суждение и умозаключение выражается формулою $a \supset b$, то историческое суждение и историческое умозаключение $\langle\ldots\rangle$ должно выражаться формулою $a \supset_{p} b$, где символ $\supset_{p}$ означает связку как функцию параметра $p$, т.е. вероятность связи $a \supset b »^{23}$. Спектр степени твердости веры или неверия в некоторую гипотезу он представляет в виде таблицы, где «плюс бесконечность» означает «абсолютно да», за чем следует нисходящая градация - «очевидно да», «быть может да» и т.п.; нулем обозначается «не знаю», за тем следует «пожалуй нет», «быть может нет», «наверняка нет», а завершается «минус бесконечностью»: «абсолютно нет» [41, том II, с. 546-547]. Далее сле-

\footnotetext{
${ }^{23}$ Курсив наш. - Б.Б., И.П.
} 
дует теоретико-вероятностное истолкование данной схемы, где наряду с математическим ожиданием вводится «нравственное ожидание».

Мы не станем подробнее говорить об этой схеме, ограничившись тем, что укажем на явное предвосхищение о.Павлом вероятностной логики, причем с учетом ее теоретико-игрового аспекта. Заметим, что данную схему Флоренский ограничивает апостериорными (т.е. эмпирическими) науками.

У Флоренского подобные рассмотрения не были связаны с нормами логики. Но в истории науки такая связь существовала издревле. Как мы знаем, еще Аристотель сомневался в универсальности «исключения третьего», размышляя об истинностной оценке высказываний о будущих событиях. В этом можно видеть отдаленное предвосхищение логической трехзначности. Естественно, что такой глубокий мыслитель, как Васильев, пошел именно этим путем. Логическая трехзначность проявляется у Н.А. Васильева, правда, не прямо - категорическая оценка его логического учения как некоей трехзначной логики, которая распространена в литературе, ошибочна ${ }^{24}$, что было показано в статье Б.В. Бирюкова и Б.М. Шуранова [?]. Почему же многие авторы находили у Васильева трехзначную логику? Потому, что в «воображаемой логике» были введены три «качества» суждений - утвердительность, отрицательность и противоречивость (в другой интерпретации - «индифферентность»). Конечно, в этом можно видеть общую идею логической трехзначности, подобную «триипостасности» Флоренского. Но Васильев в своей концепции решительно придерживался двузначности истинностных оценок суждений.

В классической пропозициональной логике имеет место совпадение бинарностей «истина - ложь»и «утвердительность - отрицательность». Отсюда законы исключенного третьего и противоречия. У Васильева первая бинарность сохраняется, а вторая заменяется тернарностью. Поэтому закон исключенного третьего заменяется законом «исключенного четвертого», а закон противоречия, утверждающий несовместимость суждений « $S$ есть $P$ и «S не есть $P$ » (или «S есть не- $P »)$ заменяется

\footnotetext{
${ }^{24} \mathrm{~K}$ сожалению, эта ошибка повторяется с настойчивостью, достойной лучшего применения. Ср. [5, с. 238]
} 
утверждением о попарной несовместимости суждений трех васильевских «качеств»: утверждения произвольного суждения $P$ (мы запишем это как $\mathrm{Y}(P)$ ), отрицания суждения $\mathrm{P}$ (запишем это как $\mathrm{O}(P))$ и нейтральной оценки $P$ (т.е. того, что $P$ «индифферентно» - $И(P))$. Тогда закон исключенного четвертого будет обязывать к выбору одного из этих суждений при отрицании остальных, а выбор этот - из трех альтернатив.

В упомянутой выше статье выбор этот был представлен таблицей несовместимостей:

\begin{tabular}{c|c|c|c} 
& $\mathrm{y}(P)$ & $\mathrm{O}(P)$ & $И(P)$ \\
\hline 1$)$ & $u$ & $\Omega$ & $\Omega$ \\
\hline 2$)$ & $\Omega$ & $u$ & $\Omega$ \\
\hline 3$)$ & $\Omega$ & $\Omega$ & $u$
\end{tabular}

где « $u »$ означало истину, а «л»- ложь. Строки же 1) - 3) предлагалось считать некими «внешними» значениями истинности трехзначной логики Васильева.

Очевидно, что в классической пропозициональной логике таблица несовместимостей имеет вид:

\begin{tabular}{c|c|c} 
& $\mathrm{y}(P)$ & $\mathrm{O}(P)$ \\
\hline 1$)$ & $u$ & $\Omega$ \\
\hline 2$)$ & $\Omega$ & $u$
\end{tabular}

А какой вид имеет таблица «несовместимостей» для металогики Васильева, прикосновенной миру «умных сущностей»? Очевидно, что это вырожденная таблица:

$$
\begin{array}{c|c} 
& \mathrm{Y}(P) \\
\hline 1) & u
\end{array}
$$

В построении Васильева выделялись три формы единичных суждений, три формы суждений общих, суждения же, которые автор «воображаемой логики» называл акцидентальными («случайными»), должны были бы быть четырех форм. Этого, однако, не происходило, так как Н.А. Васильев предполагал, что в частных суждениях (в смысле традиционной логики) квантор «некоторые» имеет смысл «только некоторые». Это уравнивает по смыслу соответствующие утвердительные и отрицательные 
суждения, и тогда таблица несовместимостей для них принимает вид:

\begin{tabular}{|c|c|c|c|}
\hline & $\begin{array}{l}\text { Tолько } \\
\text { рые некото- } \\
\text { Только } \\
\text { суть } P \text { некото- } \\
\text { рые } S \\
P\end{array}$ & $\begin{array}{l}\text { Одни } S \text { суть } P \text {, } \\
\text { а другие } S \text { суть и } \\
\text { не суть } P\end{array}$ & $\begin{array}{lr}\text { Одни } S & \text { не } \\
\text { суть } & P, \\
\text { a другие } & S \\
\text { суть и не суть } \\
P\end{array}$ \\
\hline 1) & $u$ & $\Omega$ & $\Omega$ \\
\hline 2) & $\Omega$ & $u$ & $\Omega$ \\
\hline 3) & $\Omega$ & $\Omega$ & $u$ \\
\hline
\end{tabular}

Итак, мы видим сколь многообразными были подходы к неклассической логике в России в начале XX века, даже если ограничить рассмотрение только двумя яркими представителями русской мысли того времени.

\section{5 Флоренский об антиномиях языка}

До сих пор мы, рассматривая идеи о.Павла, опирались на его труд «Столп и утверждение истины». Но выраженная в нем идея теодищеи как «оправдания Бога» - доктрина, стремящаяся «согласовать идею „благого“ и „разумного“ управления миром» с наличием в нем «мирового зла, „оправдать“ это управление перед лицом темных сторон бытия» [1] - идея эта вскоре сменилась идеей антроподицеи - «оправдания человека».

Издатель наследия о. Павла игумен Андроник (А.С. Трубачев) в предисловии к тому 3(1) собрания сочинений Флоренского приводит слова из одного его письма 1919 года: «Мой „Столп“ до такой степени опротивел мне, что я часто думал про себя: да не есть ли выпускание его в свет акт нахальства, ибо что же на самом деле понимаю я в духовной жизни?». Комментируя данный пассаж, игумен Андроник говорит, что «к этому времени ему внутренне стал чужд дух теодицеи» $[2$, с. 5-6]: «Столп» оказался пройденным этапом жизни и творчества о. Павла Флоренского. Его мышление стало развиваться в направлении антроподицеи. 
Антроподицея, как и теодицея, пишет названный выше комментатор Флоренского, есть «философия единосущия, опирающаяся на догмат о Троице. Цель антроподицеи - дедуцировать человека, т.е. показать смысл и внутреннюю необходимость его строения, освящения и деятельности, показать Божии уставы бытия человека во всех его проявлениях» [2, с. 7].

Думается, что не случайно с 1919 года Флоренского занимают проблемы физики и техники, где он активно использует свои математические знания. С начала 20-х годов Павел Александрович активно участвует в научной жизни строящегося Советского государства. Он ведет исследовательскую работу в Главэнерго, служит научным сотрудником Государственного экспериментального электротехнического института. С 1927 года интенсивно трудится в редакции «Технической энциклопедии» - и как редактор раздела «Материаловедение», входя здесь в общую редакцию издания, и как автор многочисленных статей ${ }^{25}$.

Теперь его интересует не общая проблема антиномичности богопознания, а конкретные противоречия, присущие науке и философии, а также - и прежде всего - языку. Интерес к последнему прослеживается в труде «У водоразделов мысли», где в параграфе третьем - «Мысль и язык» главы IV (она озаглавлена «Антиномии языка») ведется речь о «противоречивом сопряжении» в языке вещности и деятельности.

Внимание о. Павла к языку проистекало из его убеждения, что наука и философия представляют собой языковое описание действительности, являются противоположными модусами языка. «Наука, жесткая и по замыслу своему, на деле, в историческом своем раскрытии, имеет и текучесть, и мягкость. Философия же, подвижно-стремительная и гибкая, - таковою хочет быть, - не чужда жесткой и догматической хватки. Есть и нечто диалектическое в науке, хотя она и не диалектична по своему уклону, как есть нечто систематическое в философии» [43, c. 143$]$.

Что касается языка, то его антиномичность Флоренский раскрывает, опираясь на идеи Вильгельма Гумбольдта, которого обильно цитирует. Существо антиномии языка, по Гумбольдту,

\footnotetext{
25 Эту его деятельность прервал в 1933 г. арест, за которым последовали лагеря ГУЛАГа, а в 1937 г. расстрел.
} 
состоит в том, что в языке все живет, течет, движется; «человек - творец языка, божественно свободен в своем языковом творчестве»; это - тезис. Антитезис же заключается в том, что язык как достояние народа монументален, и пользуясь им, мы подчиняемся необходимости; «язык предстоит духу как целое, уже готовое, сразу обозреваемое, хотя, в то же время, он - только по-мгновенно творится духом и существует лишь постольку и лишь тогда, поскольку и когда творится»; язык - живое равновесие $\epsilon \rho \gamma о \nu$ и $\epsilon \nu \epsilon \rho \gamma \epsilon \iota \alpha$ [43, с. 144](также в выписках с. 5), «вещи» и «жизни». «Нет индивидуального языка, который не был бы вселенским в своей основе; нет вселенского языка, который бы не был в своем явлении - индивидуальным» [43, с. 153].

\section{6 Культурологические аспекты и социальные коннотации}

Рассмотренные нами идеи в значительной мере относились к области логики, но логическое постижение мира для П.А. Флоренского и тем более для не один раз упоминавшегося нами Н.А. Васильева не было единственным. Оба мыслителя опирались на гносеологическое учение, основы которого были заложены А.С. Хомяковым и И.В. Киреевским. Свои эпистемологические и философско-методологические предпочтения Васильев изложил в небольшой рецензии на работу Э.Л. Радлова по истории русской философии [19], в рецензии на книгу А. Пуанкаре [16, с. 392] и в Послесловии к исторической диссертации: оно было посвящено актуальным проблемам европейской культуры начала XX века. Ниже мы коснемся только одного фрагмента философско-антропологических построений казанского логика - фрагмента, посвященного роли религиозного сознания в жизни общества и значимости этого сознания при оценке окружающей действительности.

Васильев высоко ценил предлагавшуюся еще Хомяковым идею, в соответствии с которой у человека существуют три познавательных способности: разум, воля и вера. Базируя на этом свой поиск самобытной философии православного Востока, классик славянофильства именно полноту религиозной жизни считал целью всякого познания. Подлинное познание, инстру- 
ментами которого служат все три способности человека, неизбежно приводит к Богу. Это убеждение разделяет и Васильев: он, в частности, пишет о значимости религии, дающей личности устойчивые жизненные ориентиры; при этом предупреждая, что безрелигиозный путь гибелен для общества. Утрату единства смысла, свойственную атеистической цивилизации Запада (частью которого была, конечно, и императорская Россия), казанский ученый рассматривал в качестве одного из наиболее ярких симптомов вырождения. В критике основ европейской культуры этот мыслитель сходился со славянофилами. Свои размышления о ее судьбах он завершил следующей констатацией: «Наша теперешняя умственная жизнь свободна, но она анархична, разнообразна, но бессильна. Личное творчество выявляется вполне, и потому наша культура интересна и напряжена, она быстро прогрессирует, увеличивается в объеме путем постоянных личных вкладов. Но в ней нет места для грандиозного и стильного творчества прежних веков, возможного только на почве единого мировоззрения, единой идеологии, спаивавшей людей в одно творческое целое. Нам не создать ни готических соборов, ни поэм Гомера, нам не создать даже греческих трагедий, где личное в обрисовке характеров и ситуаций соединяется с одним и тем же религиозно-философским миросозерцанием, делающим из них части одного грандиозного целого. Наша культура не грандиозна, она пошла, и башня Эйфеля является ее достойным символом» $[18$, с. 131$]$.

Преемственность идей П.А. Флоренского и религиозно-философской гносеологии славянофилов и мыслителей-всеединцев более ощутима. В отличие от Васильева, Флоренский писал не об анонимной религиозности, но о церковности; как мы видели, ее нельзя понять, используя лишь инструментарий формальной логики. Церковность во всей ее конкретности, согласно Флоренскому, недоступна рассудку. Для Васильева, опиравшегося на мысли Н.А. Бердяева, Д.С. Мережковского, А. Белого и даже на иррационализм И.В. Гете [18, с. 130], противоречия в познании отражают паралогичность естественной жизни, т.е. жизни как биологического явления. Васильев, интересы которого были обращены к материальному миру, трактовал религию как инструмент, как средство достижения состояния физического и 
душевного подъема. Флоренский же писал о другом - о сверхрассудочности, реализуемой в сфере духа. Не случайно от теодищеи, воплощенной в его «Столпе. . », он перешел, как уже было говорено, к антроподищее - «оправданию человека», «испытывающего себя», усматривающего свое несоответствие образу Божию и осознающему необходимость очищения.

Существенно, что культурно-социологичеким фоном антроподицеи о. Павла было его убеждение в том, что здание культуры «духовно опустело», что «вся сложная система обездушенной цивилизации пойдет разваливаться» ${ }^{26}$, что час «глубочайшего переворота в самих основах культурного строительства» близок.

Для сверхрассудочности в понимании о. Павла критерием являлась красота духовная, а она неуловима для логических формул. Такое видение, разумеется, сильно отличается от гностического идеала религиозности, предлагавшегося Н.А. Васильевым. Если применять в отношении сказанного Флоренским категории современной теории культуры, то можно говорить о том, что феномены религиозной жизни у русского богослова являются носителями, помимо семантической, еще и глубокой эстетической информации (ср. [6]). Излагаемый религиозным мыслителем взгляд соответствует свойственному славянскому этносу эстетизму: «Повесть временных лет» свидетельствует, что именно художественная обрядность византийского православия оказала сильное впечатление на послов князя Владимира и определила выбор веры [26].

Приближение к миру совершенных сущностей, по Флоренскому, возможно через опыт. «Богословие, - писал он, - наука опытная» [41, том I, с. 122]. В этом пункте выводы русского богослова совпадают со взглядами, которые высказаны в труде Уильяма Джемса «Многообразие религиозного опыта»: «Рассудок может проложить только поверхностный и призрачный путь к Богу. $<\ldots>$ Рассудок дает темное и обманчивое знание, тогда как чувство доставляет уверенность в истине, - таково положение религиозного человека, искренне относящегося к себе самому и к фактам» [23, с. 356]. Только живая жизнь в вере,

\footnotetext{
${ }^{26} \mathrm{Cp}$. сходные пессимистические взгляды на судьбы западной цивилизации Н.А.Васильева, о которых авторы этих строк писали в [10].
} 
а не теоретизирование по поводу религии позволяет постигнуть суть, содержание последней. Надо ли говорить о том, насколько Васильев с его холодной верой естественника был далек от этой жизни.

Возвращаясь к сказанному в начале нашей работы, отметим, что сравнение Васильева и Флоренского оправдано лишь в том случае, когда они рассматриваются не только как мыслители, ставившие и решавшие ряд конкретных гносеологических и методологических проблем науки, но и как два представителя доминировавшего в начале ХХ века умонастроения, в котором ориентация на интеллектуальные традиции прошлого сочеталась с поиском новаторских решений насущных вопросов познания окружающего природного мира, общественного обустройства и духовных ценностей. Здесь мы вплотную подходим к оценке общественно-политических, мировоззренческих идей Васильева и Флоренского.

\section{$* * *$}

В русской культуре Серебряного века - как в ее западническом, так и в славянофильском варианте - наблюдалась некоторая расплывчатость оценок, понятий, характеров; часты были взаимные переходы друг в друга нетождественных явлений. Революция потребовала четкости социально-политических оценок. Власть интернационалистов-большевиков по-своему завершила эру противостояния русского западничества и почвенничества. Петербургский период русской истории подошел к концу. Но как ни парадоксально это звучит, ненавистники русской национальной культурной традиции - Ленин и Троцкий, исповедуя марксизм - порождение западной мысли, в некотором смысле продолжили дело славянофилов: противопоставили Россию «латинскому» Западу, возвратили Москве функцию столицы, протянули руку дружбы народам Востока. Так считали (и не всегда ошибочно) Н.А. Бердяев, Г.Г. Шпет, Г.В. Федоров. Надежду на большевиков как на реставраторов Московской Руси емко выразил Г.Г. Шпет: «„Славянофильская“ и даже вообще восточная порода „большевиков“ видна теперь даже философски невооруженному эмпирическому глазу. $<\ldots>$ Не случайно романтический Кремль славянофильства - реальный Кремль 
большевизма» [45, с. 85]. Да и сам Васильев в Послесловии к своей историософской книге говорил о грядущей миссии Советской России, выражая надежду, что культурное спасение деградирующей Европе придет с того географического места у притока Оки, на которое еще в XIV веке указал старец Елеазарова псковского монастыря Филофей.

Другая контроверза культурной жизни России начала XX века - это наличие и скрытое противостояние двух «незримых» сообществ - позитивистов, преобладавших в преподавательском составе университетов, людей науки вообще, с одной стороны, и деятелей искусства, для которых была характерна внерациональность мышления, базировавшегося на полурелигиозном мистико-символическом восприятии окружающего мира - с другой.

Во Флоренском и Васильеве, как нам кажется, находят выражение мировоззрение сразу обоих этих культурных сообществ. Философское мышление двух ученых как раз противоречиво объединяет несходные культурные тенденции. Здесь можно выделить две проблемы, решение которых позволяет понять специфику русской культуры начала XX века.

Первая проблема - это проблема времени. Объекты воображаемой логики Васильева взяты им вне времени. И именно отвлечение от временных характеристик позволяет рассматривать данные объекты в качестве носителей постоянных свойств. Некоторые из этих свойств являются противоречивыми - одновременно присущими и неприсущими объекту. То, что у Васильева является предметом изучения, у Флоренского оказывается предпосылкой, неотъемлемой составляющей его мысли. Всевременность и неотмирность суть необходимые признаки умопостигаемых сущностей, о которых писал религиозный мыслитель.

Требование некоторой остановки во времени и требование наличия у предмета свойств, хотя бы какое-то время остающихся неизменными, являются абсолютными для науки. В методологических исследованиях отечественных ученых разных направлений формулировка этих требований (равно как и напоминание: мыслить предмет в целостности его основных свойств) в ХХ веке появляется неоднократно. Естественно, что его учитывал и Васильев, и Флоренский.

Вторая проблема - это уже обсуждавшаяся нами проблема 
объектов, несущих в себе противоречие и опровергающих своим существованием закон исключенного третьего. Особенно много таких объектов, как мы уже говорили, порождает социальная реальность. Противоречивые социальные феномены, отражавшиеся в работах русских философов конца XIX - начала XX в., можно считать эмпирическими референтами закона исключенного четвертого Н.А. Васильева и учения об антиномичности П.А. Флоренского. Нередко в трудах отечественных ученых предлагался выбор не из двух, а из трех альтернатив, причем одна из них противоречиво сочетала свойства двух других. Даже политический контекст русских революций, как нам кажется, встраивается в подобную схему. Ведь среди основных сил, участвовавших в ней, обычно называют не только революционеров («красных») и противостоящих им консервативные силы (нередко отождествляемые с «черными» - так называемыми черносотенцами, обскурантами - от лат. obscurus - темный), но и либеральную интеллигенцию, принципиально отвергавшую крайности тех и других. Россия как культурный ареал мыслился отечественной историософией не как механическое смешение Запада и Востока, но как особый мир, в котором противоречивое объединение разнородных культурных элементов порождает самобытные культурные комплексы. Разве не о России и не о ее творческом гении идет речь в следующем фрагменте Е.Н. Трубецкого: «Не один только потусторонний мир Божественной славы нашел себе изображение в древнерусской иконописи. В ней мы находим живое, действенное соприкосновение двух миров, двух планов существования. С одной стороны - потусторонний вечный покой, с другой стороны - страждущее, греховное, хаотическое, но стремящееся к успокоению в Боге существование, мир ищущий, но не нашедший Бога» [36, с. 41]. И встреча этих двух миров есть «третье»- самое Россия.

$$
* * *
$$

Мы видим, что идеи Флоренского заставляют обратиться к положениям, лежавшим в основе логических изысканий начала XX века. В самом деле, одним полюсом у Флоренского и философов-всеединцев XX века является онтологическое ничто - то, чему нет места в мире. Это ничто, тем не менее, 
тщится занять какое-то место. Оно хочет если не быть, то хотя бы казаться чем-либо. На онтологическую фиктивность лжи указывал наряду с Флоренским Андрей Белый, связывавший ее с темнотой, мраком: «Отсутствие... божественного рождает черную пустоту $\langle\ldots>$ Открывается: ужас - бездна пошлости. Носится серая стая, осаждаясь повсюду. Душит и гасит светоч жизни, слабо мерцающий в руках... » [36, с. 42]. Иначе обстоит дело с истиной: она, как указывал Флоренский, «включается всем», т.е. в отличие от лжи, бездны она на «законных основаниях» присутствует во всем, придает бытийный статус вещам и явлениям. Ее всеохватность не имеет ничего общего с тривиальной логической общезначимостью. То, как Флоренский понимал ложь, естественно связать с пустыми формулами идеологий: их пустота явилась именно следствием их общезначимости [9]. Она - от отсутствия границ, например, между предметом $A$ и всем, что не- $A$. Истина же включается во все, но не разрушает границ вещей и явлений. Важно, что именно так понимал истину и Н.А. Васильев. Ложь в металогике Васильева невозможна психологически. Генератором металогических рассуждений является сверхприродное Существо, неспособное ошибаться, а значит, неспособное лгать. Исключая ложь из объектов мысли, автор «воображаемой логики» лишал ее онтологического статуса.

Сильно отличалась от «васильевского» восприятия лжи как онтологической фикции концепция, предлагавшаяся некоторыми представителями школы логического позитивизма. Эта западная школа может быть представлена как антитеза русской философии. В онтологии одного из представителей данного философского направления - Дж. Мура «Отец лжи» не просто реальность, но первая реальность: он более реален, чем Бог. Именно на это указывал Мур в одной из лекций, прочитанной на заседании кружка кембриджских «апостолов»: «В начале была материя, она породила дьявола, а дьявол породил Бога» [31, c. 153].

Анализ наследия Н.А. Васильева и П.А. Флоренского позволяет говорить о связи, существующей между формами рели- 
гиозного сознания и логикой. Истоки неклассических воззрений Флоренского в логике понятны: они коренятся в «мирочувствии» его как православного священника. Иначе обстоят дела с Васильевым. Последний высоко оценивал религию, но не как личный путь к совершенству, а как форму общественного, коллективного сознания. Именно общественные, «мирские» стороны религиозной жизни принимал он во внимание. В сочинениях своего деда - выдающегося востоковеда В.П. Васильева - он мог бы ознакомиться с тем, как в традиционном восточном обществе бок о бок с развитием религиозного сознания происходило становление логики и диалектики. Казанский ученый мог бы обратить внимание на то, что в основном произведении его дедаисторика - трактате о буддизме подчеркивалась наукообразующая роль религии [15, с. 169-170]. В.П. Васильев показывает, что потребность разрешать религиозные противоречия в мире средневекового буддийского общества была мощным стимулом развития логики.

Понимая значимость веры, Васильев-внук не жил подлинной религиозной жизнью. Ею жил Флоренский. Однако и последнего ортодоксальные авторы нередко упрекают в склонности к рационалистическому обоснованию фактов веры. Иногда грех чрезмерного упования на разум формулируется достаточно резко - как мудрствование плоти. В этой специфической особенности мышления обнаруживается еще одно сходство научных биографий Васильева и Флоренского: поиски того и другого нередко заводили их в интеллектуальные тупики. Поэтому, чтобы понять масштаб философских заслуг двух русских мыслителей, чтобы оценить глубину не только их мыслей, но и заблуждений, чтобы осознать непреходящее значение их естественнонаучных и историософских прозрений, необходимо учитывать особенности логических учений обоих исследователей. Сделать это мы и попытались.

\section{Литература}

[1] Аверинцев С.С. Теодицея // Новая философская энциклопедия. Том 4. М., 2001. C. 31.

[2] Игумен Андроник (А.С. Трубачев). История создания цикла «У водоразделов мысли» // Свящ. Павел Флоренский. Сочинения в четырех томах. Том 3(1). М.: «Мысль», 1999. 
[3] Асмус В.Ф. Формальная логика и диалектика // Под знаменем марксизма. 1929. №.4. C. 39-62.

[4] Бажанов В.А. Становление и развитие логических идей Н.А. Васильева // Философские науки. 1986. № 3. С. 74-82.

[5] Бажанов B.A. История логики в России и СССР (концептуальный контекст университетской философии). М.: Канон, 2007.

[6] Бирюков Б.В. Строгость терминологии и стиль мышления // Психология процессов художественного творчества. Л.: Наука, 1980. С. 261-264.

[7] Бирюков Б.В. Из истории математической логики в России: «Задача Кэрролла» в трактовке о. Павла Флоренского // Логические исследования. Вып. 6. M., 1999.

[8] Бирюков Б.В. Неклассические идеи в русской философской логике конца XIX - начала XX века // Смирновские чтения. 2 Международная конрференция. M., 1999.

[9] Бирюков Б.В. Социальная мифология, мыслительный дискурс и русская культура // Homo legens-3. Человек читающий. Сб. статей. М., 2006.

[10] Бирюков Б.В., Прядко И.П. «Где все единство без конца ... ». Логические воззрения Н.А.Васильева в культурно-философском контексте Серебряного века // Вопросы философии. 2003. № 1.

[11] Бирюков Б.В., Тростников В.Н. Жар холодных числ и пафос бесстрастной логики. Формализация мышления от античных времен до эпохи кибернетики. Изд. 3-е, переработанное и дополненное. М., 2004.

[12] Бирюков Б.В., Шуранов Б.М. В каком смысле «воображаемую логику» Н.А. Васильева можно считать многозначной // Вестник МГУ. Серия 7: философия, 1998, № 5 .

[13] Бугаев Н.В. Математика и научно-философское миросозерцание // Вопросы философии и психологии, 1898. № 45

[14] Васильев А.В. Целое число. Пг., 1919.

[15] Васильев В.П. Буддизм, его догматы, история и литература. Ч.І. СПб., $1857-$ 1869.

[16] Василъев Н.А. Рецензия на книгу: Henri Poincare. Dernieres pensees (Paris, 1913. Ernest Flammarion edit.) // Логос. 1913. № 3-4.

[17] Васильев Н.А. Рецензия на книгу Ф. Полана «Логика противоречий»// Логос [Международный Ежегодник по философии культуры]. М.: Мусагет, 1913.

[18] Васильев H.A. Вопрос о падении Западной Римской империи и античной культуры в историографической литературе и истории философии // Известия общества археологии, истории и этнографии при Казанском университете. Т. III. Вып. 2 -3. Казань, 1921. С. 118-248.

[19] Василъев Н.А. Рецензия на «Очерк истории русской философии» Э. Радлова // Казанский библиофил. 1921, №2. С.98-99.

[20] Васильев Н.А. Логика и металогика // Васильев Н.А. Воображаемая логика. M., 1989.

[21] Васильев Н.А. Рецензия на книгу В. Виндельбанда и А. Руге «Энциклопедия философских наук» // Васильев Н.А. Воображаемая логика. М., 1989.

[22] Васильев Н.А. Воображаемая (неаристотелева) логика // Васильев Н.А. Воображаемая логика. М., 1989. Первая публикация этой второй статьи Васильева см.: Журнал Министерства народного просвещения, Н.с. 1912, август. Ч. 40. C. 207-246.

[23] Джемс У. Многообразие религиозного опыта. СПб., Андреев и сыновья, 1993.

[24] Дмитриева Н. Предисловие // Фохт Б.А. Избранное (из философского наследия). М.: Прогресс-Традиция, 2003. С. 38.

[25] Кутюра Л. Алгебра логики. Перев. П. Слешинского. Одесса, 1909. 
[26] Летопись по Ипатьевскому списку // Русские летописи. Т. II. Рязань: Александрия, 2001. С. 73-74.

[27] Поварнин С.И. Спор. О теории и практике спора. М., 1992.

[28] Половинкин С.М. Аритмология // Новая Философская энциклопедия. Т. І. М., 2000. С. 179.

[29] Прлдко И.П. История как проблема логики в диссертационном исследовании Н.А.Васильева (методологические аспекты исторической концепции создателя «воображаемой логики») // Современная логика: Проблемы теории, истории и применения в науке. Материалы научной конференции. СПб., 2004.

[30] Пуанкаре A. Мораль и наука // Пуанкаре А. Последние мысли. Пг., 1923. C. 117.

[31] Рассел Б. Автобиография // Вопросы философии. 2004, № 5. С. 150-154.

[32] Савелъев А.Л. К вопросу о структуре античной диалектики // Современная логика: проблемы теории, истории и применения в науке. Материалы V Общероссийской научной конференции. СПб., 1998.

[33] Смирнов В.А. Логические взгляды Н.А. Васильева // Очерки по истории логики в России. М., 1962.

[34] Смирнов В.А. Аксиоматизация логических систем Н.А. Васильева // Современная логика и методология науки. М., 1987. С. 143-151.

[35] Смирнов В.А. Логические методы анализа научного знания. М., 1987.

[36] Трубецкой E.Н. Два мира в древнерусской иконе // Е.Н. Трубецкой. Три очерка о русской иконе. Новосибирск: Сибирь XXI век, 1991.

[37] Флоренский П.А. О символах бесконечности (Очерк идей Г. Кантора) // Новый путь. 1904, № 9. С. 173-235.

[38] Флоренский П.А. Космологические антиномии Канта. С приложением экскурса об антиномической структуре разума // Богословский вестник. 1909. Том 1, № 44; цит. по: Свящ. Павел Флоренский. Сочинения в четырех томах. Том 2. М., «Мысль», 1996.

[39] Флоренский П.А. Пифагоровы числа // Сочинения в четырех томах. Том 2. М.: «Мысль», 1996. С. 632-646.

[40] Флоренский П.А. А.С. Хомяков // Богословский вестник. 1916, июль-август.

[41] Флоренский П.А. Столп и утверждение истины. Тома I-II. М., 1990 (Факсимильное издание труда, подзаголовок которого гласил: «Опыт православной теодицеи в двадцати письмах свящ<енника > Павла Флоренского», Изд-во «Путь», M., 1914).

[42] Флоренский П.А. Иконостас. М.: Искусство, 1994.

[43] Флоренский П.А. Сочинения в четырех томах. Т.3(1). М.: «Мысль», 1996.

[44] Хоружий C.C. Философский символизм Флоренского и его жизненные истоки // Историко-философский ежегодник. М.: Наука, 1988. С. 180-201.

[45] Шnет Г.Г. Очерк развития русской философии. Ч. І. Петроград: Колос, 1922.

[46] Шрейдер Ю.А. Лекции по этике. М.: МИРОС, 1994.

[47] Шрейдер Ю.А. Этика: введение в предмет. М.: Текст, 1998.

[48] Шуранов Б.М. Русская логика переломной эпохи (1880-1930) в социокультрологическом аспекте. Автореф. дисс. на соиск. уч. степ. канд. филос. наук. М., 2000.

[49] Шуранов Б.М., Бирюков Б.В. Русские неокантианцы: предвосхищение идей логической паранепротиворечивости // Научная конференция «Современная логика: проблемы теории, истории и применения в науке». Памяти И.Н.Бродского и О.Ф.Серебрянникова. Тезисы докладов. СПб., 1996. 
[50] Шуранов Б.М., Бирюков Б.В. Об одной контроверзе в истолковании логики мышления. С.А.Богомолов против Н.А.Васильева // Тезисы докладов международного семинара «Антропология с современной точки зрения». Калининград, 1998.

[51] Arruda A. Vasiliev: A forerunner of paraconsistent logic // Philosophia naturalis. 1984. Vol. 21. P. 472-491.

[52] Arruda A. Vasiliev: A forerunner of paraconsistent logic // VII International Congress of Logic, Methodology and Philosophy of Science. Salzburg. Vol. 6. P. 1417.

[53] Biryukov B.V. Die Antizipation nichtklassischer Ideen durch russische Logiker des 19. und Anfang des 20. Jahrhunderts // W.Stelzner / M.Stockler (Hrsg.). Zwischen traditioneller und moderner Logik. Nichtklassische Ansatze. Paderborn, mentis Verlag, 2001.

[54] Paulhan Fr. La logique de la contradiction. Paris: Felix Alean, 1911. 